\author{
UNIVERSIDADE DE SÃO PAULO \\ FACULDADE DE MEDICINA DE RIBEIRÃO PRETO \\ DEPARTAMENTO DE GENÉTICA \\ PROGRAMA DE PÓS-GRADUAÇÃO EM GENÉTICA
}

\title{
EFEITOS DA PRÓPOLIS DE ABELHAS AFRICANIZADAS E MELIPONÍNEOS EM MICROORGANISMOS
}

\begin{abstract}
ANA PAULA FARNESI
Dissertação de Mestrado apresentada à Faculdade de Medicina de Ribeirão Preto da Universidade de São Paulo, para obtenção do título de Mestre em Ciências - Área de concentração: Genética.
\end{abstract}

RIBEIRÃO PRETO

2007 
UNIVERSIDADE DE SÃO PAULO

FACULDADE DE MEDICINA DE RIBEIRÃO PRETO

DEPARTAMENTO DE GENÉTICA

PROGRAMA DE PÓS-GRADUAÇÃO EM GENÉTICA

EFEITOS DA PRÓPOLIS DE ABELHAS AFRICANIZADAS E MELIPONÍNEOS EM MICROORGANISMOS

ANA PAULA FARNESI

Dissertação de Mestrado apresentada

à Faculdade de Medicina de Ribeirão

Preto da Universidade de São Paulo, para obtenção do título de Mestre em Ciências - Área de concentração:

Genética.

Orientador: Prof. Dr. ADEMILSON ESPENCER EGEA SOARES RIBEIRÃO PRETO

2007 
FICHA CATALOGRÁFICA

Farnesi, Ana Paula

Efeitos da própolis de abelhas africanizadas e meliponíneos em microorganismos. Ribeirão Preto, 2007. 73 p:il; 30cm.

Dissertação apresentada à Faculdade de Medicina de Ribeirão Preto-USP. Área de concentração: Genética.

Orientador: Prof. Dr. Ademilson Espencer Egea Soares.

1. Própolis 2. apiterapia 
Autora: Ana Paula Farnesi

Título: Efeitos da própolis de abelhas africanizadas e meliponíneos em microorganismos

\begin{tabular}{c}
\hline Prof(a) Dr(a) \\
\hline $\operatorname{Prof}(a) \operatorname{Dr}(a)$ \\
$\operatorname{Prof}(a) \operatorname{Dr}(a)$
\end{tabular}

Trabalho defendido e aprovado pela Comissão Julgadora em 
Dedico este trabalho:

À Deus pela minha existêncía.

Aos meus pais Aurélio e Dalva e ao meu irmão Victor Hugo, por todo apoio, amor e pelo incentivo ao meu trabalho.

Ao meu namorado Diogo por todo o amor, paixão, compreensão, companheirismo, amizade e paciência durante a realização deste trabalho.

Ao meu grande amigo e orientador Prof. Dr. Ademilson Espencer Egea Soares, pela colaboração, sabedoría e amizade. 


\section{Agradecimentos}

Ao Prof. Dr. Ademilson Espencer Egea Soares, pela amizade, carinho, apoio e orientação.

Ao Prof. Dr. Jairo Kennup Bastos, pelo grande apoío na realização deste trabalho.

À Profa. Dra. Nille María Martinez Rossi, pelas sugestões, confiança e grande apoio na realização deste trabalho.

Ao Prof. Dr. João Atílio, pela atenção, paciência, ajuda e amizade.

$\mathcal{A}$ o Prof. Dr. Sérgio Brito, por toda confiança e grande sabedoría.

Ao Sr. Wilson Melo, pelo fornecimento da própolis da abelha Scaptotrigona sp (Tubi), para a realização deste trabalho.

Ao Prof. Dr. Lionel Segui Gonçalves, pelos ensinamentos com o manejo de abelhas, pela amizade e por todo apoio.

Ao técnico Maurício (Departamento de Mícrobiologia da FFCL-USP), pela amizade e ajuda técnica.

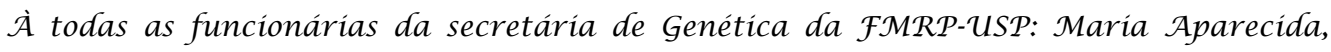
Susie e Cleuza, pela atenção e ajuda burocrática.

À todos os amigos de laboratório de Farmacognosia: Niege, Sérgio, Ademar, Nilton, Gustavo, Ana Silvia, William, João Paulo e Walter, pelos momentos de descontração e lições de vida.

À todos os amigos de laboratório de Microbiologia: Luiz, Uberaba, Jardinópolis, Paraná, Vivian pelos momentos de descontração.

À todos os amigos de laboratório de Genética Molecular de Microorganismos: Fernanda Maranhão, Fernanda Paíão, Geni, Nalu, Dianna, Ana Cláudia, Roselí, Juliana e Dona Geralda, pela amizade e apoio nos momentos dificeis. 
Aos amigos de laboratório de Patologia: Luiz Fernando, Cleverson, Aline, Rose e Patrícia, pela amizade e momentos alegres.

À todos os amigos de laboratório de Genétíca de abelhas: Anete, Michelli, Fernanda, Rodrigo, Tiago, Carlitos, Weyder, Rogério, Michelli Prioli, Sérgio, David, Aline, Omar, Umberto, Vera, Adriana, Amanda, Ana Rita, Camilas, Marina, Vanessa, Tita, Ivan, Geusa, Érika, Robertos, Grão, Lili, Francis, Sérgio, Mônica, Paulo Emilio, Gesline, Karina, Profa. Márcia, Profa. Dra. Zílá, Prof. Dr. Klaus, Prof. Dr. David, Prof. Dr. Lionel, Jairo, João, Adelino e Luiz Roberto pela amizade, descontração e pelas lições de vida.

Em especial à minha grande amiga Marcela Bezerra, pela amizade, pelo carinho e pelos momentos felizes, que foram muitos.

Ao meu namorado Diogo por todo o amor, paixão e todos os dias de alegria, que foram e serão eternos.

$\mathcal{A}$ todos os meus familiares por tudo.

Às instituições $C \mathcal{A P E S}$ e $C \mathcal{N} \mathcal{P} q$, pela ajuda financeira oferecida na realização deste trabalho.

$\mathcal{A}$ todos que de alguma forma me esqueci de citar nestes agradecimentos mas que contribuiram direta e indiretamente para a realização deste trabalho.

Muito Obrigada!

Ana Paula Farnesí 
Sumário

LISTA DE ABREVIATURAS E SÍMBOLOS..................................................

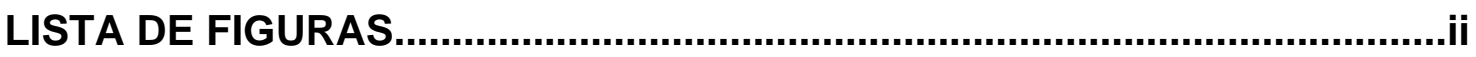

LISTA DE TABELAS

RESUMO

ABSTRACT

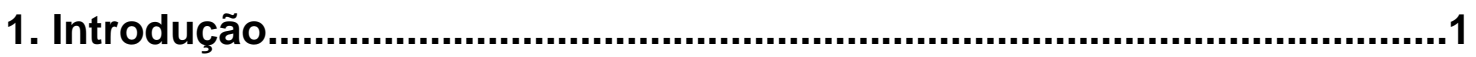

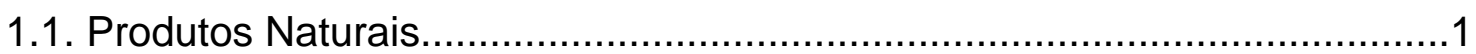

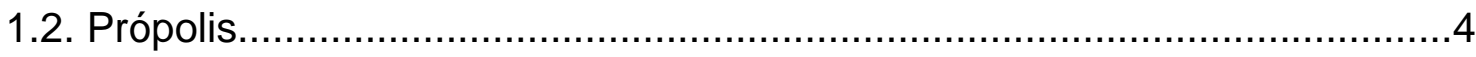

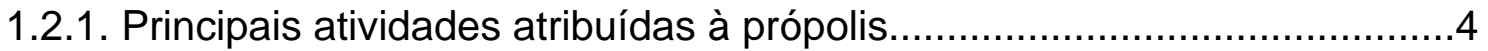

1.2.2- Principais substâncias encontradas na própolis e fatores que influenciam

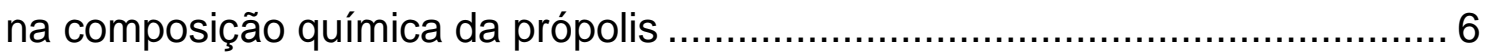

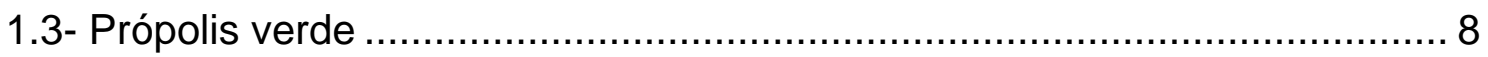

1.4- Atividades biológicas da própolis verde ................................................ 9

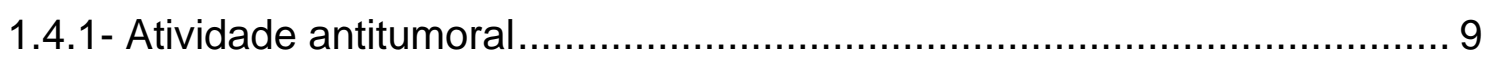

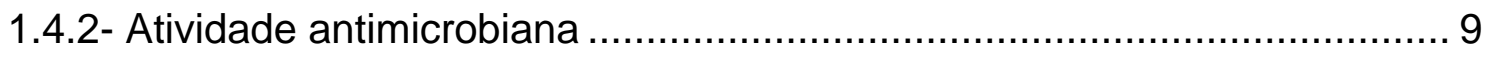

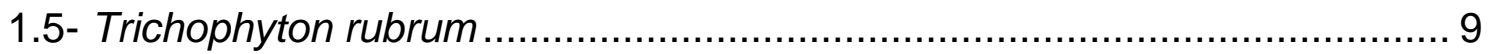

1.6- Aspergillus nidulans como modelo experimental....................................12

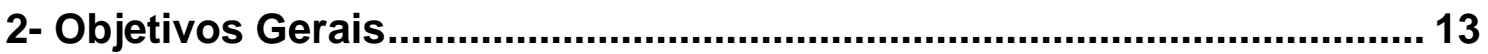

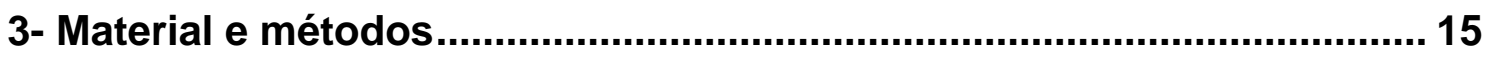

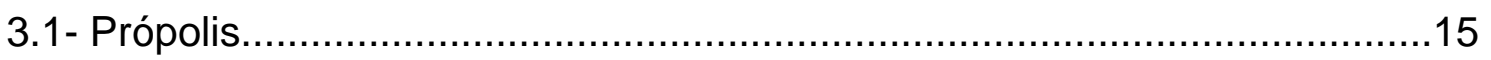

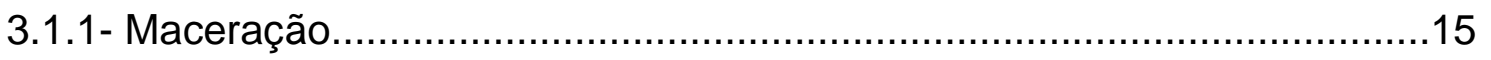

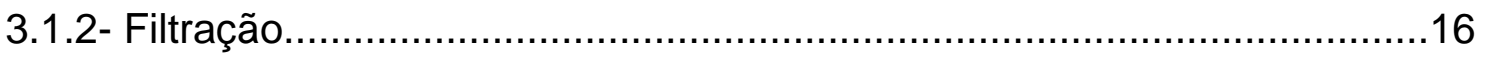

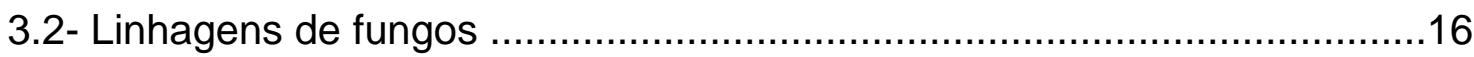

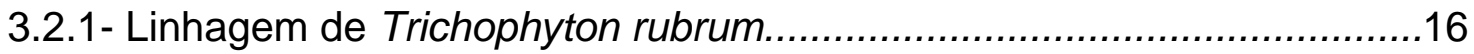

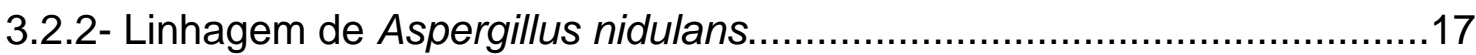

3.3- Manutenção e estoque das linhagens de fungos....................................17

3.3.1- Linhagens de Trichophyton rubrum e Aspergillus nidulans....................17

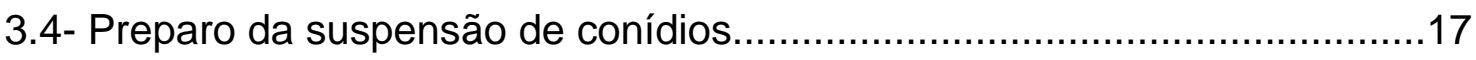

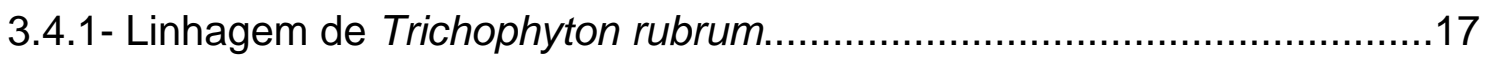

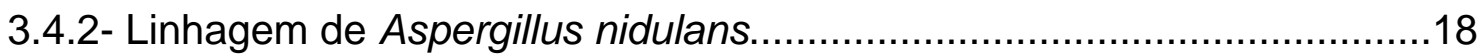

3.5- Determinação da concentração inibitória mínima CIM...............................18 
3.5.1- CIM pelo método de microdiluição para Aspergillus nidulans. 19

3.5.2- CIM pelo método de microdiluição para Trichophyton rubrum .................20

3.5.3- CIM pelo método de microdiluição para Pseudomonas aeruginosa.......21

3.5.4- CIM pelo método de microdiluição para Micrococcus luteus..................21

3.5.5- CIM pelo método de microdiluição para Staphylococcus aureus............22

3.5.6- CIM pelo método de microdiluição para Escherichia coli........................23

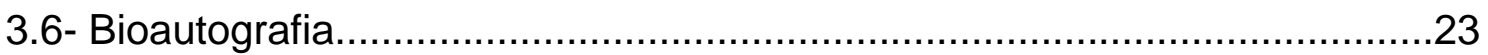

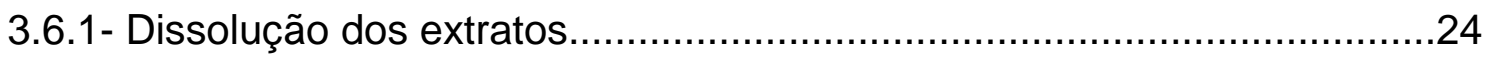

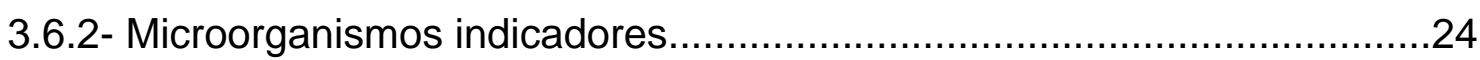

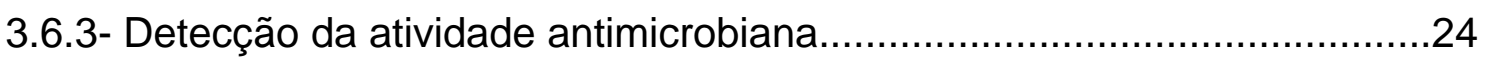

3.7- Determinação do perfil químico dos extratos hidroalcoólicos das diferentes

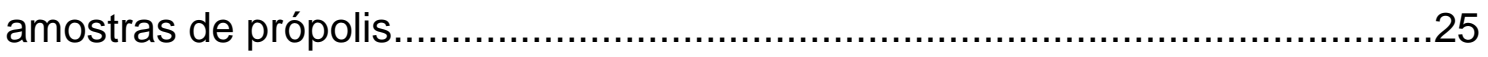

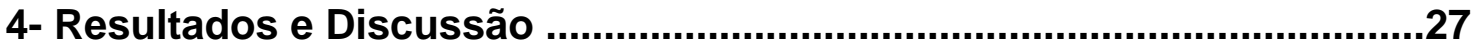

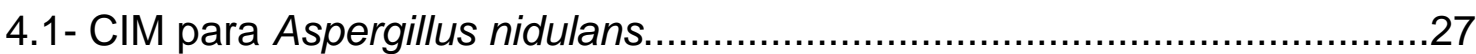

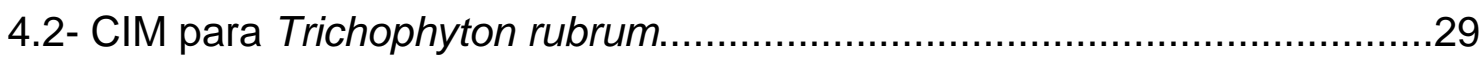

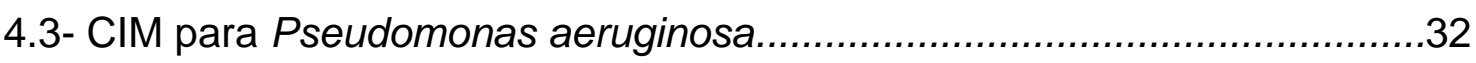

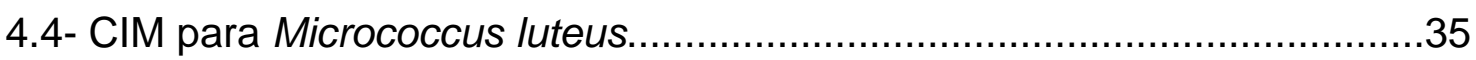

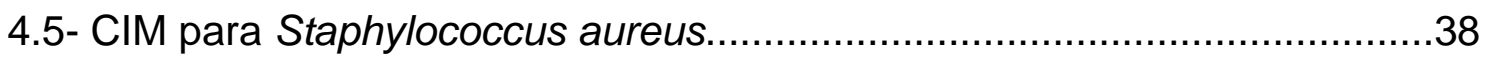

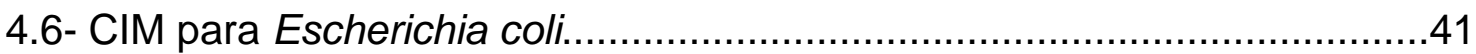

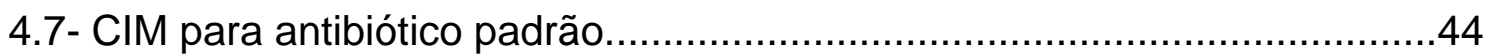

4.8- Avaliação da atividade antibacteriana.................................................... 47

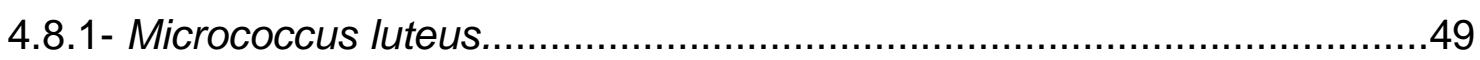

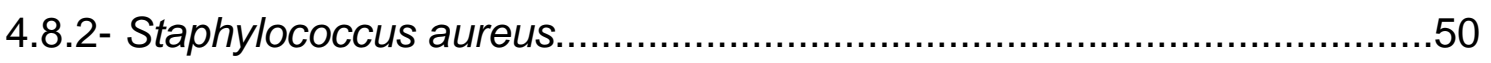

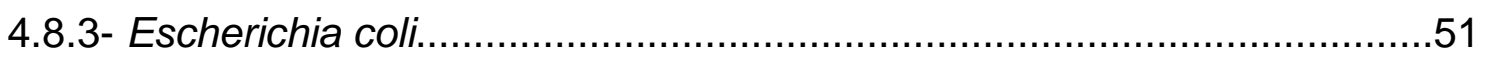

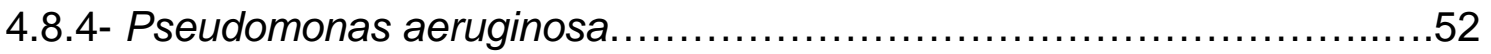

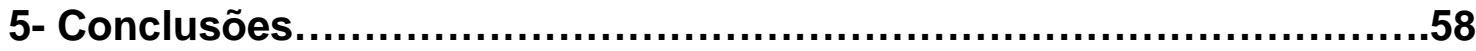

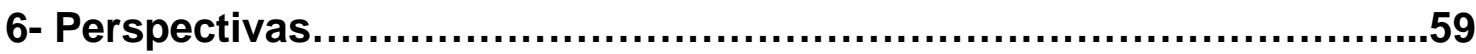

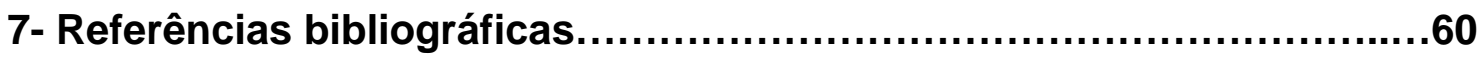

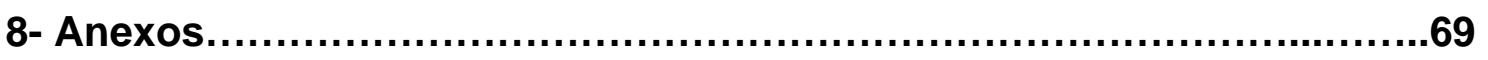




\section{LISTA DE ABREVIATURAS E SÍMBOLOS}

CIM: concentração inibitória mínima

CLAE: cromatografia líquida de alta eficiência

+: indica o crescimento do microorganismo na concentração correspondente

- : indica a inibição do microorganismo na concentração correspondente

HCL: ácido clorídrico

MeOH: metanol

$\mathrm{NaOH}$ : hidróxido de sódio

NCCLS: Comitê de Laboratório Clínico Padrão

TSA: meio de cultura Triptona Soja Ágar

TSB: meio de cultura Triptona Soja Caldo. 


\section{LISTA DE FIGURAS}

FIGURA 1- Cromatograma do extrato hidroalcoólico da própolis verde (Apis mellifera), coletada em janeiro de 2005, detecção em 280nm. 46

FIGURA 2- Cromatograma do extrato hidroalcoólico da própolis da abelha indígena Melipona quadrifasciata, coletada em janeiro de 2005, detecção em $280 \mathrm{~nm}$

FIGURA 3- Cromatograma do extrato hidroalcoólico da própolis da abelha indígena Scaptotrigona sp, coletada em janeiro de 2005, detecção em 280 $\mathrm{nm}$.

FIGURA 4- Cromatograma do extrato hidroalcoólico da própolis da abelha indígena Melipona compressipes fasciculata, coletada em janeiro de 2005, detecção em $280 \mathrm{~nm}$

FIGURA 5- Imagem da placa de cromatografia em camada delgada comparativa utilizada para determinação da atividade antibacteriana dos seguintes extratos: $A=$ própolis verde $B=$ própolis da abelha indígena Scaptotrigona sp; $\mathrm{C}=$ própolis da abelha Melipona quadrifasciata, frente ao Micrococcus luteus por meio de Bioautografia. 49

FIGURA 6- Imagem da placa de cromatografia em camada delgada comparativa utilizada para determinação da atividade antibacteriana do extrato de própolis da abelha Melipona quadrifasciata, frente ao Micrococcus luteus por meio de Bioautografia.

FIGURA 7- Imagem da placa de cromatografia em camada delgada comparativa utilizada para determinação da atividade antibacteriana dos seguintes extratos: $A=$ própolis verde (Apis mellifera); $B=$ própolis da abelha Scaptotrigona sp; $\mathrm{C}=$ própolis da abelha Melipona quadrifasciata frente ao Staphylococcus aureus, por meio de Bioautografia. .50

FIGURA 8- Imagem da placa de cromatografia em camada delgada comparativa utilizada para determinação da atividade antibacteriana da própolis 
da abelha Melipona quadrifasciata, frente ao Staphylococcus aureus, por meio de Bioautografia.

FIGURA 9- Imagem da placa de cromatografia em camada delgada comparativa utilizada para determinação da atividade antibacteriana dos seguintes extratos: $A=$ própolis da abelha Scaptotrigona $\mathrm{sp}$; $B=$ própolis verde (Apis mellifera); $\mathrm{C}=$ própolis da abelha Melipona quadrifasciata frente a Escherichia coli, por meio de Bioautografia .51

FIGURA 10- Imagem da placa de cromatografia em camada delgada comparativa utilizada para determinação da atividade antibacteriana dos seguintes extratos: $A=$ própolis da abelha Scaptotrigona $\mathrm{sp} ; \mathrm{B}=$ própolis verde (Apis mellifera); frente a Escherichia coli, por meio de Bioautografia. .51

FIGURA 11- Imagem da placa de cromatografia em camada delgada comparativa utilizada para determinação da atividade antibacteriana da própolis da abelha Melipona quadrifasciata, frente a Escherichia coli, por meio de Bioautografia .52

FIGURA 12- Imagem da placa de cromatografia em camada delgada comparativa utilizada para determinação da atividade antibacteriana dos seguintes extratos: $A=$ própolis verde (Apis mellifera); $B=$ própolis da abelha Scaptotrigona sp; $\mathrm{C}=$ própolis da abelha Melipona quadrifasciata frente a Pseudomonas aeruginosa, por meio de Bioautografia. .52 FIGURA 13- Imagem da placa de cromatografia em camada delgada comparativa utilizada para determinação da atividade antibacteriana dos seguintes extratos: $A=$ própolis verde (Apis mellifera); $B=$ própolis da abelha Scaptotrigona $s p$; frente a Pseudomonas aeruginosa, por meio de Bioautografia. .53

FIGURA 14- Imagem da placa de cromatografia em camada delgada comparativa utilizada para determinação da atividade antibacteriana da própolis da abelha Melipona quadrifasciata, frente a Pseudomonas aeruginosa, por meio de Bioautografia. 
Tabela 1 - Gradiente multi-linear de eluição para análise qualitativa em CLAE de amostras de própolis. .26

Tabela 2: Diferentes concentrações de própolis das abelhas: Scaptotrigona sp, Melipona compressipes fasciculata, Apis mellifera e Melipona quadrifasciata testadas frente ao Aspergillus nidulans.

Tabela 3: Diferentes concentrações de própolis das abelhas: Tetragonisca angustula, Plebeia droryana, Scaptotrigona bipunctata, Friesiomelitta varia, Nannotrigona testaceicornis testadas frente ao Aspergillus nidulans. 28

Tabela 4: Diferentes concentrações de própolis das abelhas: Scaptotrigona sp, Melipona compressipes fasciculata, Apis mellifera, Melipona quadrifasciata e Tetragonisca angustula testadas frente ao Trichophyton rubrum 30

Tabela 5: Diferentes concentrações de própolis das abelhas: Scaptotrigona bipunctata, Friesiomelitta varia, Plebeia droryana e Nannotrigona testaceicornis testadas frente ao Trichophyton rubrum.

Tabela 6: Diferentes concentrações de própolis das abelhas: Scaptotrigona sp, Apis mellifera, Melipona quadrifasciata e Tetragonisca angustula testadas frente à Pseudomonas aeruginosa.

Tabela 7: Diferentes concentrações de própolis das abelhas: Plebeia droryana, Scaptotrigona bipunctata, Friesiomelitta varia e Nannotrigona testaceicornis, testadas frente à Pseudomonas aeruginosa. 34

Tabela 8: Diferentes concentrações de própolis das abelhas: Scaptotrigona sp, Apis mellifera, Plebeya droriana e Tetragonisca angustula, testadas frente à Micrococcus luteus. 36

Tabela 9: Diferentes concentrações de própolis das abelhas: Melipona quadrifasciata, Scaptotrigona bipunctata, Friesiomelitta varia e Nannotrigona testaceicornis, testadas frente à Micrococcus luteus. 
Tabela 10: Diferentes concentrações de própolis das abelhas: Scaptotrigona sp, Apis mellifera, Tetragonisca angustula e Nannotrigona testaceicornis, testadas frente à Staphylococcus aureus. .39

Tabela 11: Diferentes concentrações de própolis das abelhas: Melipona quadrifasciata, Plebeia droryana, Scaptotrigona bipunctata e Friesiomelitta varia testadas frente à Staphylococcus aureus. 40

Tabela 12: Diferentes concentrações de própolis das abelhas: Scaptotrigona $s p$, Apis mellifera e Melipona quadrifasciata, testadas frente à Escherichia coli.

Tabela 13: Diferentes concentrações de própolis das abelhas: Tetragonisca angustula, Plebeia droryana, Scaptotrigona bipunctata, Friesiomelitta varia e Nannotrigona testaceicornis, testadas frente à Escherichia coli.

Tabela 14: Protocolo de antibiótico padrão para Pseudomonas aeruginosa, Escherichia coli, Micrococcus luteus e Staphylococcus aureus. 44 


\section{Resumo}

O presente trabalho teve por objetivo estudar a atividade antifúngica e antibacteriana de diferentes tipos de própolis, tanto de abelhas africanizadas (verde) quanto meliponíneos. A concentração inibitória mínima, sendo a menor concentração de um agente inibidor em que não se observa o crescimento macroscópico do microorganismo, foi determinada para todas as amostras de própolis. Para análise do perfil químico das amostras foi utilizada como metodologia (CLAE), visando determinar as classes de substâncias presentes nas amostras de própolis. Em todos os microorganismos testados as própolis das abelhas Tetragonisca angustula, Plebeia droryana, Scaptotrigona bipunctata, Friesiomelitta varia e Nannotrigona testaceicornis não apresentaram atividade antifúngica nem antibacteriana. Nenhuma das amostras de própolis testadas apresentou atividade antifúngica frente ao Aspergillus nidulans. A linhagem do fungo Trichophyton rubrum mostrou-se sensível a alguns tipos de própolis sendo que a própolis verde foi mais eficaz. Alguns tipos de própolis apresentaram atividade antibacteriana, indicando a importância dessas resinas na terapêutica humana e veterinária.

Palavras-chave: propolis, apiterapia. 
Abstract

Our objective was to examine the antifungal and antibacterial activities of several types of propolis, including Africanized honey bee green propolis and propolis produced by meliponini bees. The minimal inhibitory concentration, considered to be the lowest concentration of an inhibitory agent in which there is no macroscopic growth of the microorganism, was determined for all the propolis samples. CLAE methodology was used for the analysis of the chemical profiles of the samples, in order to determine the classes of substances in the propolis samples. Propolis from the bees Tetragonisca angustula, Plebeia droryana, Scaptotrigona bipunctata, Friesiomelita varia and Nannotrigona testaceicornis presented no antifungal or antibacterial activity. None of the propolis samples presented antifungal activity against Aspergillus nidulans. The fungus Trichophyton rubrum was sensitive to several types of propolis, green propolis being the most efficient against this species. Various types of propolis also presented antibacterial activity, demonstrating the potential importance of these resins for human and veterinary medicine.

Key-Words: propolis, apitherapy. 


\section{1- Introdução}

\section{1- Produtos Naturais}

Há muitos anos, as drogas vêm sendo as formas de intervenção terapêutica disponíveis aos médicos, mais amplamente usada no combate às infecções. As principais fontes de novas drogas são agora os produtos químicos sintéticos, mas os produtos naturais ainda são importantes em diversas afecções.

As primeiras descrições sobre produtos naturais feitas pelo homem remontam às sagradas escrituras e ao papiro de Ebers. Esse papiro foi descoberto e publicado por Georg Ebers, sendo traduzido pela primeira vez em 1890, por H. Joachin. Foi encontrado nas proximidades da casa mortuária de Ramsés II, porém pertence à época da XVIII dinastia. Enumera mais ou menos 100 doenças e descreve um grande número de drogas de natureza animal e vegetal (Vilela 1977).

Durante a civilização grega, vários filósofos podem ser destacados por suas obras sobre história natural. Dentre esses, sobressaem-se Hipócrates, considerado o pai da medicina moderna, que se caracterizou por tomar a natureza como guia na escolha dos remédios (Natura medicatrix) e Teofrasto (372 a.C), discípulo de Aristóteles, que escreveu vários livros sobre a história das plantas. É seu o registro da utilização da espécie botânica Papaver somniferum, planta cujo princípio ativo é a morfina (Valle 1978). 
No século I da era cristã, destaca-se o eminente médico grego Dioscóride, autor de notável obra sobre medicina e farmácia intitulada "De Materia Medica", que serviu como guia de ensino nestas áreas até a época do Renascimento. No mesmo século, o naturalista latino Plínio, cognominado "O Velho", escreveu extensa obra sobre história natural. No século seguinte sobressai Galeno, farmacêutico e médico grego, autor de vários livros sobre medicina e farmácia. Suas formulações medicamentosas originaram a farmácia galênica.

A civilização árabe trouxe importante contribuição à medicina natural. $A$ ela deve-se o emprego dos purgativos vegetais e o conhecimento do sabor doce da urina dos diabéticos. No século $X$, impõem-se o nome do médico islâmico Avicena (Abu Ali al Hussin ibn Abdallah ibn Sina), estudioso botânico, criador de um tratado sobre medicamentos cardíacos. Sua obra mais importante "Canon", foi durante muito tempo o texto médico mais popular da Europa (Mahran 1977).

Todo o empirismo mágico-feiticeiro da arte de curar ao longo da história da humanidade, das teriagas às mandrágoras, encontra em Paracelso (14931541) sua figura mais polêmica. É sua a criação da teoria da "assinatura dos corpos" segundo a qual a "atividade farmacológica" de uma planta estaria relacionada com o seu aspecto morfológico. Assim, por exemplo, a serpentária, erva da família das aráceas cuja haste malhada lembra o corpo de uma serpente, serviria para a cura de picadas de cobras (Mors, 1982). 
As grandes navegações trouxeram a descoberta de novos continentes, legando ao mundo moderno um grande arsenal terapêutico de origem vegetal até hoje indispensável à medicina.

As culturas americanas, especialmente a Inca, Asteca, Maya, Olmeca e Tolteca consignaram à civilização moderna a quina, a ipecacuanha, a coca e muitas outras drogas de valor terapêutico

O isolamento das primeiras substâncias puras do reino vegetal começa a acontecer no século XVIII. Nesse século, juntamente com o XIX, foram feitos diversos trabalhos de extração, principalmente de ácidos orgânicos e de alcalóides. São desta época o isolamento de morfina (1806), quinina e estriquinina (1820).

Após a metade do século XVIII, Lavoisier destruiu a teoria do flogístico criando as bases da química moderna ao estabelecer a natureza da combustão, permitindo desse modo a determinação da composição centesimal das substâncias orgânicas.

O final dos anos vinte e toda a década de trinta do século XX pode ser caracterizado pelo grande número de trabalhos sobre o isolamento e a identificação de substâncias de natureza esteroidal.

A introdução dos métodos espectroscópicos e das diferentes modalidades de cromatografia na fitoquímica alterou gradualmente os objetivos e a filosofia dos trabalhos de isolamento e de determinação estrutural de Produtos Naturais.

A utilização de métodos espectroscópicos em identificação estrutural permitiu a redução das quantidades do material necessário à análise e 
possibilitou, ao mesmo tempo, a determinação em curto espaço de tempo de estruturas complexas.

\section{2- Própolis}

Há relatos históricos que a própolis tem sido utilizada desde a antiguidade quando os egípcios embalsamavam os faraós, com uma mistura de ervas e própolis. O estudo sobre a própolis iniciou-se no Instituto de Veterinária em Kazan (URSS), em 1947, investigando suas propriedades antimicrobianas e curativas.

A própolis é um produto natural, tendo uma ampla ação biológica tanto para o homem quanto para os animais, podendo ser utilizado na medicina humana e veterinária.

A própolis (Grego; pro, em defesa + polis, cidade) é utilizada pelas abelhas para selar eventuais aberturas na colméia, para proteção contra microorganismos e como substância embalsamadora que recobrem as carcaças.

\subsection{1-Principais atividades biológicas atribuídas à própolis}

Acredita-se que a própolis é utilizada pelo homem desde o ano 300 a.C. Atualmente, vem sendo utilizada por suas atividades antiséptica, antimicótica, bacteriostática, antiinflamatória, anestésica, antioxidante, cicatrizantes, entre outras. Suas aplicações, também na área dermatológica, são muito amplas, tais como na regeneração de tecidos, tratamento de queimaduras, psoríases, 
herpes simples e genital. É utilizada em cremes dentais, produtos farmacêuticos e cosméticos, podendo ser encontrada sob a forma de tabletes, pó e goma de mascar (Burdok 1998).

Nos últimos anos, diversos estudos mostraram que a própolis possui atividades: antiviral (Debiaggi et al.,1990; Amoros et al.,1992), antibacteriana (Ikeno et al.,1991; Aga et al.,1994; Mirzoeva et al., 1997; Park e Ikegaki., 1998; Abd e Hegazi, 2002; Ugur e Arslan, 2004, Sonmez et al., 2005; Uzel et al., 2005; Lu et al., 2005; Popova et al., 2005; Scazzocchio et al., 2006), antifúngica (Valdes et al., 1987; Dobrowolki et al., 1991; Oliveira et al., 2006, Sawaya et al., 2002, Ota et al., 2001; Koc et al., 2005; Ozcan 2004; Silici \& Koc, 2006, Aly \& Elewa, 2007) e contra protozoários (Higashi e Castro, 1994, Silva Cunha et al., 2004). A própolis de abelhas nativas (sem ferrão), tais como: Tetragonisca angustula, Nannotrigona testaceicornis, Scaptotrigona sp., Partamona, Melipona sp, mostraram que são altamente eficazes contra Staphylococcus aureus, Escherichia coli (Fernandes et al., 2001, Miorin et al., 2003).

De acordo com Velikova et al., (2000) a própolis da abelha Melipona quadrifasciata apresenta atividade moderada contra Staphylococcus aureus.

Além dessas atividades, foi também descrita a ação sobre a regeneração cartilaginosa e óssea (Burdok, 1998), atividade antitumoral (Rao et al., 1992; Frenkel et al., 1993; citados por Burdok, 1998), cardioprotetora (Chopra et al., 1995; Cook \& Samman., 1995; Hollman et al., 1996), imunomoduladora (Havsteen.,1983; Ivanoska et al., 1995), e antimutagênica (Cizmarick \& Lahitova.,1998; Varanda et al.,1999). 
Alguns trabalhos que detectaram a atividade antimutagênica da própolis (Cizmarick e Lahitova,1998; Varanda et al.,1999), sugeriram que esta ação poderia estar associada ao potencial antioxidante dos flavonóides presentes em sua composição química (Krol et al.,1990; Scheller et al., 1990; Volpert e Elstner.,1993; Pascual et al.,1994; Said.,2000).

Vários estudos têm mostrado a atividade anticancerígena de alguns componentes da própolis, dentre eles os ésteres do ácido cafeico (Rao et al.,1992; 1993; 1995; Frenkel et al., 1993; Matsuno et al.,1997; Kimoto et al.,1998). Acredita-se que a atividade desses componentes possa estar relacionada ao metabolismo do ácido araquidônico, inibindo a progressão do

câncer. Compostos isolados da própolis brasileira, como o Artepelin C (3,5 diprenil- 4- ácido hidroxicinâmico) e o diterpenóide clerodana (PRF-1) apresentaram atividade citotóxica sobre células tumorais, in vivo e in vitro, inibição da síntese de DNA e indução de apoptose nestas células (Matsuno et al., 1997; Kimoto et al.,1998).

\subsection{2- Principais substâncias encontradas na própolis e fatores que influenciam na composição química da própolis}

Há grande dificuldade em padronizar a composição química da própolis, uma vez que fatores geográficos, sazonais e climáticos podem exercer influência sobre as plantas, que são fontes da própolis (Cheng e Wong, 1996).

A identificação dos componentes da própolis tem sido realizada por técnicas de cromatografia líquida de alta perfomance (Bankova et al.,1992; Barberán et al.,1993), cromatografia gasosa em coluna capilar (Bankova et al., 
1992) e espectrometria de massa (Greenaway et al.,1991), que demonstraram a grande complexidade e diversidade destes componentes.

Ainda que não tenha sido completamente definida a composição da própolis, que inclui ácidos graxos e fenólicos (incluindo ácido cinâmico e cafeico) e seus ésteres, aldeídos aromáticos, alcóois, sesquiterpenos, naftalenos e flavonóides. Dentre estes compostos, os flavonóides e os derivados do ácido cafeico, como o fenetil éster (CAPE) e o benzil cafeato, despertam especial interesse por serem apontados como os principais responsáveis pelas atividades terapêuticas relacionadas à própolis (Bankova, et al.,1983; Amoros et al., 1992; Marcucci, 1995).

$\mathrm{Na}$ própolis brasileira, ocorrem principalmente compostos fenólicos, especialmente flavonóides como a flavona e o campeferide e derivados do ácido cinâmico (Boudourova-Krasteva et al., 1997; Bankova et al., 1998). Entretanto, foi observado que, dependendo da estação do ano, existe variação dos componentes; Os diterpenos, por exemplo, são detectados na própolis produzida durante o verão e outono, mas não estão presentes na própolis produzida nas outras estações do ano (Bankova et al.,1998).

Dentre as substâncias já identificadas da própolis européia, destacam-se os flavonóides (flavonas, flavonóis e flavononas), chegando a alcançar concentrações em torno de $10 \%$ em algumas amostras e apresentando mais de 30 flavonóides aglicônicos diferentes (Campos et al., 1990, Marcucci, 1996).

Diferentes flavonóides foram isolados e identificados em amostras de própolis de várias regiões do mundo, como por exemplo: kaempferide, apigenina, crisina, luteolina, pinobankisina, narigenina, aromadendrina-4`-metil 
éter, 5,6,7-triidroxi-3,4' -dimetoxiflavona, acacetina, alpinol, entre outros (Bankova et al.,1992; Banskota et al., 1998; Boudorava-Krasteva et al., 1997; Garcia-Vigueira et al., 1992; Koo \& Park, 1997; Martos et al., 1997; Markam et al., 1996; Pereira et al., 1998; Siess et al., 1996; Vennat et al., 1995). Algumas atividades biológicas da própolis são atribuídas aos flavonóides tais como: antioxidante, antimicrobiana, antiinflamatória, antifúngica, analgésica entre outras (Aga et al., 1994; Marcucci, 1996).

Por outro lado estudos revelaram que a própolis brasileira, principalmente dos estados de São Paulo e Minas Gerais, são constituídas majoritariamente por derivados de ácido-p-cumárico. Estas substâncias possuem marcantes atividades biológicas, como por exemplo: antitumoral e antimicrobiana, mas estão ausentes na própolis européia, norte-americana e asiática (Marcucci e Bankova, 1999).

\section{3- Própolis verde}

Este tipo de própolis é produzida no cerrado brasileiro, rica em derivados prenilados, é conhecida no mundo todo com "green propolis", apresentando fragmentos da planta Baccharis dracunculifolia, que possui uma coloração característica, e é utilizada principalmente pelos japoneses. Quanto maior o número de fragmentos de Baccharis dracunculifolia presente na própolis mais intensa é a sua coloração verde (Bastos, 2001). 


\section{4- Atividades biológicas da própolis verde}

\subsection{1- Atividade antitumoral}

A própolis verde tem sido utilizada principalmente no Japão, na profilaxia e também para auxiliar o tratamento de vários tipos de cânceres, com isso apresenta um alto valor no mercado. O ácido 3,5-diprenil-p-cumárico, isolado desta própolis possui efeito protetor para carcinonomas pulmonares (Kimoto et al., 2001a) e atividade antileucêmica (Kimoto et al., 2001b).

\subsection{2- Atividade antimicrobiana}

AGA et al., (1994), demonstraram que o ácido-3,5-diprenil-p-cumárico, isolado da própolis coletado no estado de São Paulo, possui alta atividade antimicrobiana contra 18 cepas de microorganismos.

\section{5- Trichophyton rubrum}

As infecções micóticas possuem ampla variedade e difusão, apresentando manifestações clínicas diversas, seguindo a natureza dos tecidos em que se localizam. As infecções podem ser desde superficiais até profundas. Ambas as enfermidades micóticas induzem estados alérgicos. A diferenciação do gênero, espécie e variedade têm base nos critérios morfológicos e reprodutivos.

Dermatófitos são fungos queratinofílicos, que produzem queratinases causadpras de infecções na pele, cabelos e unhas, atingindo tanto indivíduos hígidos quanto imunodeprimidos. Tais fungos são classificados em três 
gêneros anamórficos: Trichophyton, Epidermophyton e Microsporum, sendo que cada gênero apresenta formação e morfologia de seus conídios (estrutura de reprodução assexuada) diferentes, sendo que são divididos em espécies zoofílicas, geofílicas ou antropofílicas (Kwon-Chung e Bennett, 1992). As micoses profundas apresentam um grupo heterogêneo que afeta as mucosas e vísceras.

Neste grupo a Candida albicans ocupa um lugar muito importante sendo uma forma intermediária entre dermatófitos e microorganismos que causam infecções profundas.

O Trichophyton rubrum, é o dermatófito mais comum do mundo sendo responsável por causar a maioria das infecções na pele.

De um modo geral, o controle das infecções fúngicas depende inicialmente dos complexos e mecanismos de defesa de cada hospedeiro. Se a doença se instalar quando ocorrer falha nesta defesa, será necessário utilizar drogas fungicidas ou fungistáticas que atuem contra os patógenos no intuito de evitar danos ao hospedeiro.

As infecções causadas por determinados tipos de fungos podem causar doenças desde o extrato córneo da pele até fígado, baço, pulmão, coração e rins. Em geral doenças causadas por fungos tendem a ser benigmas, sendo que as micoses podem ser classificadas como: superficiais, cutâneas, subcutâneas, profundas e oportunistas. As micoses cutâneas ocorrem em tecidos queratinizados como: pele, unhas, cabelos e pêlos.

O grau de lesão se deve ao conjunto de vários fatores como a magnitude de destruição tecidual, estado imunológico do hospedeiro, 
habilidade do agente em se multiplicar (Baron 1996). A infecção com dermatófitos ocorre através do contato direto com animais e humanos infectados, ou indiretos, através de fômites contaminados (Weitzman e Summerbell, 1995).

Os sintomas podem variar, desde brandos até mais graves sendo que geralmente não ocorre invasão de órgãos internos. As lesões dermatofílicas são: eritematosas, circulares e pruriginosas, podendo estar presente em diversas partes do corpo. O dermatófito mais freqüente isolado em casos clínicos de Tinea pedis (pés), Tinea corporis (corpo), Tinea mannum (mão), Tinea unguium (unhas) e Tinea cruris (virilha) é o Trichophyton rubrum (Anstey et al., 1996; Zais e Rebell, 1996; Foster et al., 2004).

Este mesmo patógeno foi responsável por 48,63\% dos casos de dermatofitoses na cidade de São Paulo no período de 1992 a 2002 (Chinelli et al., 2003) e 49,72\% em Goiânia no período de janeiro a dezembro de 1999 (Costa et al., 2002). Em Lausanne (Suíça) e em Nova York, este patógeno foi responsável, respectivamente por $62,5 \%$ e $67 \%$ dos casos de onicomicose (unha), (Monod et al., 2002; Jennings et al., 2002).

O dermatófito obtém do hospedeiro, nutrientes para sua sobrevivência tais como: fonte de carbono, enxofre, fósforo e nitrogênio.

As lesões menos inflamatórias causadas por Trichophyton rubrum são mais crônicas e resistentes (Sohnle, 1993; Wagner e Sohnle, 1995; Ogawa et al., 1998). 


\section{6- Aspergillus nidulans como modelo experimental}

O fungo Aspergillus nidulans é um modelo biológico conveniente para estudos de mecanismos de resistência a drogas.

Seu ciclo de vida pode ser tanto sexual quanto assexual. Possui hifas multinucleares que produzem esporos assexuais ou conídios. Apesar de ser um fungo homolático é possível fazer cruzamentos entre linhagens distintas deste organismo. Quando colocadas em contato, ocorre fusão de hifas com os núcleos geneticamente distintos passando a ocupar o mesmo citoplasma (heterocários). A fusão destes núcleos origina núcleos diplóides com 16 cromossomos, os quais sofrem meiose seguida de mitose formando os chamados ascósporos. Há ainda a possibilidade de formação do heterocário que, ao invés de sofrer meiose, sofrerá não disjunções sucessivas até que o estado haplóide estável seja atingido (ciclo parassexual). A análise das colônias geradas permite a identificação de genes e o seu mapeamento genético ao longo dos 8 grupos de ligação do Aspergillus nidulans. 


\section{2- Objetivos Gerais}

Estudar e avaliar as atividades in vitro de diferentes tipos de própolis, tanto de abelhas africanizadas (Apis mellifera) quanto de meliponíneos (Scaptotrigona sp., Plebeia droryana, Melipona quadrifasciata, Melipona compressipes fasciculata, Scaptotrigona bipunctata, Nannotrigona testaceicornis, Friesiomelitta varia e Tetragonisca angustula) contra a patogenicidade de: Aspergillus nidulans, Trichophyton rubrum, Staphylococcus aureus, Escherichia coli, Pseudomonas aeruginosa e Micrococcus luteus.

Determinar as Concentrações Inibitória Mínima (CIM) de acordo com o Comitê Nacional de Laboratório Clínico Padrão com o método de microdiluições.

Para atingir este objetivo, os seguintes aspectos foram abordados:

- Obtenção das linhagens dos seguintes fungos: Aspergillus nidulans e Trichophyton rubrum.

- Obtenção de linhagens das seguintes bactérias: Staphylococcus aureus, Micrococcus luteus, Pseudomonas aeruginosa e Escherichia coli.

- Análise do crescimento das linhagens;

- CIM das linhagens de Aspergillus nidulans, Trichophyton rubrum Staphylococcus aureus, Micrococcus luteus, Pseudomonas aeruginosa e Escherichia coli.

- Obtenção de extratos hidroalcoólicos e obtenção de extratos brutos secos de todas as amostras de própolis coletadas; 
- Cromatografia de camada delgada (Bioautografia) das seguintes bactérias: Staphylococcus aureus, Micrococcus luteus, Pseudomonas aeruginosa e Escherichia coli. 


\section{3- Material e métodos}

\section{1- Própolis}

A própolis verde foi obtida na cidade de Capetinga, estado de Minas Gerais, em janeiro de 2005. A própolis da abelha Scaptotrigona sp., foi obtida na cidade Barra do Corda no estado do Maranhão em janeiro de 2005, a própolis da abelha Melipona compressipes fasciculata foi obtida em janeiro de 2005 na cidade de São Luis no estado do Maranhão. Já as própolis das abelhas: Melipona quadrifasciata, Plebeia droryana, Scaptotrigona bipunctata, Nannotrigona testaceicornis, Friesiomelitta varia e Tetragonisca angustula, foram obtidas no Departamento de Genética da Faculdade de Medicina de Ribeirão Preto, USP na cidade de Ribeirão Preto, estado de São Paulo.

Para a extração das substâncias ativas em um breve tempo foi necessária a pulverização, para aumentar a superfície de contato com o solvente, facilitando deste modo à extração.

\subsection{1-Maceração}

A extração dos primeiros princípios ativos da própolis foi realizada mediante a utilização de álcool 70\%, à temperatura ambiente, sendo macerada por 48 horas. Foi ainda agitada seis vezes ao dia, pois a agitação acelera e melhora o processo de extração, (em média $30 \mathrm{~g}$ de própolis pulverizada em 100mL de etanol 70\%). 


\subsection{2- Filtração}

Para separar o extrato de própolis dos resíduos, foi empregada a primeira fase de decantação, depois de uma filtração prévia, mediante um filtro a vácuo. A filtração filtração fina foi efetuada através de papel filtro, em um aparato a vácuo. O filtrado foi levado para um Rotaevaporador, a $80^{\circ} \mathrm{C}, 115$ rpm, para a obtenção do extrato da própolis.

O extrato da própolis foi armazenado em frascos âmbar, levado a estufa a $45^{\circ} \mathrm{C}$ por 7 dias para eliminação de água. Posteriormente, foi armazenado em vidros âmbar, foi tampado hermeticamente e armazenado à temperatura ambiente.

\section{2- Linhagens de fungos.}

\subsection{1- Linhagem de Trichophyton rubrum}

Os ensaios antifúngicos foram realizados no laboratório de Genética Molecular de Microorganismos, do departamento de Genética da Faculdade de Medicina de Ribeirão Preto - USP, sob supervisão da Prof. Dra. Nilce M. Martinez-Rossi.

A linhagem H6 (ATCC MYA-3108) de Trichophyton rubrum utilizada neste trabalho foi isolada de um paciente, do Hospital das Clínicas da Faculdade de Medicina de Ribeirão Preto, USP, portador de Tinea cruris. Esta linhagem foi identificada através do método de McGinnis (1980) pela Profa. Dra. Cláudia Maria Leite Maffei, responsável pelo setor de Micologia do Departamento de Biologia Celular e Molecular e Bioagentes Patogênicos 
da Faculdade de Medicina de Ribeirão Preto, USP. As características desta linhagem são: colônia branca de aspecto cotonoso e encorpado, o reverso da colônia não apresenta pigmentação após 15 dias de crescimento em meio Ágar Saboraud (Atlas, 1993). Estudos de seu cariótipo mostraram a presença de pelo menos cinco cromossomos e o seu genoma apresenta aproximadamente 22,05 Mbp (Cervelatti et al., 2004).

\subsection{2-Linhagem de Aspergillus nidulans}

A linhagem de Aspergillus nidulans utilizada neste trabalho foi paba A1.

\section{3- Manutenção e estoque das linhagens de fungos.}

\subsection{1- Linhagens de Trichophyton rubrum e Aspergillus nidulans}

Para a preservação da linhagem Trichophyton rubrum MYA-3108 por períodos mais longos, foram utilizados tubo de ensaio contendo meio Ágar Sabouraud inclinado (Atlas, 1993). Para a preservação de Aspergillus nidulans por um período longo, foram utilizados grânulos de sílica gel.

\section{4-Preparo da suspensão de conídios}

\subsection{1- Linhagem de Trichophyton rubrum}

A linhagem de H6 (ATCC MYA-3108) de Trichophyton rubrum foi cultivada por 14 dias a $28^{\circ} \mathrm{C}$ em meio Ágar Sabouraud. Após este período, o micélio foi coletado com o auxílio de uma espátula estéril e colocado em solução salina 0,9\%(m/v) acrescida de Tween 80 0,01\%(v/v). Em seguida, a mistura foi agitada vigorosamente para desagregar os conídios, filtrada através 
de lã de vidro para a remoção das hifas e centrifugada a 2000 rpm por 10 minutos, em centrífuga clínica à temperatura ambiente. O precipitado foi ressuspendido em solução salina $0,9 \%(\mathrm{~m} / \mathrm{v})$ e a concentração de conídios desta solução foi estimada através da contagem em câmara de Neubauer.

\subsection{2- Linhagem de Aspergillus nidulans}

A linhagem de Aspergillus nidulans foi cultivada em meio Completo suplementado com $2 \mathrm{~mL}$ de glicose e $2 \mathrm{~mL}$ de nitrato para cada $100 \mathrm{~mL}$ de meio. Após este período, o micélio foi coletado como auxílio de uma espátula estéril e colocado em solução salina $0,9 \%(\mathrm{~m} / \mathrm{v})$ acrescida de Tween 80 0,01\%(v/v). Em seguida, a mistura foi agitada vigorosamente para desagregar os conídios, filtrada através de lã de vidro para a remoção das hifas e centrifugada a 2000 rpm por 10 minutos, em centrífuga clínica à temperatura ambiente. O precipitado foi ressuspendido em solução salina $0,9 \%(\mathrm{~m} / \mathrm{v})$ e a concentração de conídios desta solução foi estimada através da contagem em câmara de Neubauer.

\section{5- Determinação da concentração inibitória mínima CIM.}

Esta técnica foi utizada para se saber a menor concentração de própolis que inibe o crescimento macroscópico dos microorganismos.

O teste foi realizado em placas de 96 poços em triplicata, sendo incubadas a $28^{\circ} \mathrm{C}$ por sete dias para Trichophyton rubrum e quatro dias para Aspergillus nidulans. Após este período, foi observado o crescimento dos fungos através da turvação do meio de cultivo. Meio de cultivo sem inóculo, 
meio sem própolis mas com inóculo e meio com etanol 1\% foram utilizados como controles.

A CIM foi determinada para as linhagens das seguintes bactérias: Pseudomonas aeruginosa, Micrococcus luteus, Staphylococcus aureus e Escherichia coli. O teste foi realizado em placas de 96 poços em triplicata, sendo incubadas em estufa a $37^{\circ} \mathrm{C}$ por 24 horas.

\subsection{1- CIM pelo método de microdiluição para Aspergillus nidulans}

Este experimento foi realizado para verificar se os extratos das própolis exercem alguma ação sobre Aspergillus nidulans. O procedimento foi realizado segundo estabelecido pelo Comitê Nacional de Padronização (NCCLS)documento M-38a. Uma alíquota de $0,1 \mathrm{~mL}$ de uma suspensão de conídios contendo $3,9 \times 10^{4}$ conídios/mL correspondente a uma transmitância de 80-82\% a 530nm, as seguintes amostras de própolis foram inoculadas em meio RPMI: própolis da abelha Scaptotrigona sp., própolis da abelha Melipona quadrifasciata, própolis da abelha Melipona compressipes fasciculata, própolis da abelha Plebeia droryana, própolis da abelha Scaptotrigona bipunctata, própolis da abelha Nannotrigona testaceicornis, própolis da abelha Friesiomelitta varia e própolis da abelha Tetragonisca angustula e própolis verde. Para todas as amostras de própolis foram utilizadas as seguintes concentrações: $0.01,0.022,0.045,0.09,0.1875,0.375,0.75,1.5,3.0$; e 3.75, 7.5, 15.0, 30.0, 60.0, 120.0, 240.0, $480.0 \mathrm{mg} / \mathrm{mL}\left(4 \times 10^{4}\right.$ conídios $\left./ \mathrm{mL}\right)$. O teste foi realizado com placas de 96 poços em triplicata. As placas foram incubadas por quatro dias e após este período o crescimento do fungo foi observado. 


\subsection{2- CIM pelo método de microdiluição para Trichophyton rubrum}

Este experimento foi realizado para verificar se os extratos das própolis exercem alguma ação sobre Trichophyton rubrum. Uma alíquota de 0,1mL de uma suspensão de conídios contendo $5 \times 10^{4}$ conídios $/ \mathrm{mL}$, correspondente a uma transmitância de $70-75 \%$ a 530nm, as mesmas amostras de própolis (item 3.5.1), foram testadas para Trichophyton rubrum. Foram utilizadas as seguintes concentrações: $0.001,0.002,0.004,0.008,0.016,0.032,0.064,0.11,0.23$,

0.46, 0.93, 1.87, 3.75, 7.5, 15.0 e $30.0 \mathrm{mg} / \mathrm{mL}$ (contendo $5 \times 10^{4}$ conídios/ mL) . O teste foi realizado em placas de 96 poços em triplicata. As placas foram incubadas por sete dias e após este período o crescimento do fungo foi observado.

Outras concentrações foram testadas para própolis da abelha Scaptotrigona sp. e Melipona quadrifasciata: 15, 16.5, 22.5, 25.5, 27.5, 30 $\mathrm{mg} / \mathrm{mL}$, (contendo $1,7 \times 10^{4}$ conídios $/ \mathrm{mL}$ ), 27.5, 28.5, 29.5 e $30.0 \mathrm{mg} / \mathrm{mL}$, (contendo $5,3 \times 10^{4}$ conídios $/ \mathrm{mL}$ ).

Outras concentrações foram testadas para própolis da abelha Melipona compressipes fasciculata: 15.0, 20.0, 25.0, 30.0, (contendo $1,7 \times 10^{4}$

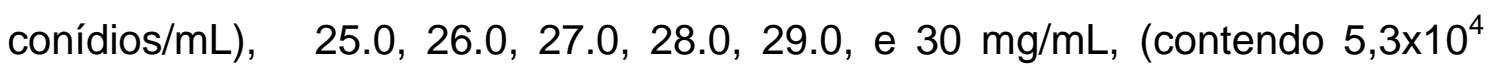
conídios/mL).

Outras concentrações foram testadas para própolis verde: 3.75, 4.0, 4.5, 5.5, $7.5 \mathrm{mg} / \mathrm{mL}$, (contendo $1,7 \times 10^{4}$ conídios $/ \mathrm{mL}$ ), 5.5, 6.5, e $7.5 \mathrm{mg} / \mathrm{mL}$. (contendo $5,3 \times 10^{4}$ conídios $/ \mathrm{mL}$ ). 


\subsection{3- CIM pelo método de microdiluição para Pseudomonas aeruginosa}

Pseudomonas aeruginosa foi replicada em tubos de ensaio contendo TSB e incubada em estufa a $37^{\circ} \mathrm{C}$ por 24 horas. Posteriormente, foi transferida para tubos contendo Müller Hinton ágar por 24 horas. Utilizando uma alça de platina esterilizada o microrganismo indicador foi transferido para tubo contendo $5 \mathrm{~mL}$ de solução salina, padronizada comparativamente com tubo 0,5 da escala de MacFarland $(0,05 \mathrm{~mL}$ de cloreto de bário a 1,0\% + 9,95 mL de ácido sulfúrico a 1,0\%). Diluições sucessivas foram realizadas até a obtenção de um inóculo de $10^{7}$ células/mL. A suspensão obtida foi adicionada ao meio

Müeller Hinton na proporção de 2 \%, obtendo-se o inóculo. Foram utilizadas as mesmas amostras de própolis (item 3.5.1), com as seguintes concentrações: $400.0, \quad 350.0, \quad 250.0,200.0,190.0,180.0,170.0,160.0,150.0,140.0,130.0$, $120.0,110.0,100.0,90.0,80.0,70.0,60.0$ e $50.0 \mu \mathrm{g} / \mathrm{mL}$.

Para a própolis verde, foram testadas as seguintes concentrações: 400, 399, 398, 397, 396, 395, 394, 393, 392, 391, 380, 370, 360, $350 \mu \mathrm{g} / \mathrm{mL}$.

Para a própolis da abelha Melipona quadrifasciata, foram testadas as seguintes concentrações: 200.0, 199.0, 198.0, 197.0, 196.0, 195.0, 194.0, 193.0, 192.0, 191.0, $190.0 \mu \mathrm{g} / \mathrm{mL}$.

\subsection{4- CIM pelo método de microdiluição para Micrococcus luteus}

Para Micrococcus luteus foram utilizados os mesmos procedimentos descritos para Pseudomonas aeruginosa (item 3.5.3) para obtenção do inóculo. Foram utilizadas as mesmas amostras de própolis (item 3.5.1), nas seguintes 
concentrações: 400.0, 350.0, 250.0, 200.0, 190.0, 180.0, 170.0, 160.0, 150.0, $140.0,130.0,120.0,110.0,100.0,90.0,80.0,70.0,60.0$ e $50.0 \mu \mathrm{g} / \mathrm{mL}$.

Para a própolis verde, foram testadas as seguintes concentrações: $190.0,189.0,188.0,187.0,186.0,185.0,184.0,183.0,182.0,181.0,180.0$ $\mu \mathrm{g} / \mathrm{mL}$.

Para a própolis da abelha Scaptotrigona sp., foram testadas as seguintes concentrações: 350.0, 349.0, 348.0, 347.0, 346.0, 345.0, 344.0, 342.0, 341.0, 340.0, 330.0, 320.0 $\mu \mathrm{g} / \mathrm{mL}$.

Para a própolis da abelha Melipona quadrifasciata, foram testadas as concentrações: 250.0, 245.0, 240.0, 239.0, 238.0, 237.0, 236.0, 235.0 230.0, 220.0, 210.0, $220.0 \mu \mathrm{g} / \mathrm{mL}$.

\subsection{5- CIM pelo método de microdiluição para Staphylococcus aureus}

Para Staphylococcus aureus foram utilizados os mesmos procedimentos descritos para Pseudomonas aeruginosa (item 3.5.3) para obtenção do inóculo. Foram utilizadas as mesmas amostras de própolis (item 3.5.1), nas seguintes concentrações: 400, 350, 250, 200, 190, 180, 170, 160, 150, 140, 130, 120 , $110,100,90,80,70,60$ e $50 \mu \mathrm{g} / \mathrm{mL}$.

Para a própolis verde, foram testadas as concentrações: 250.0, 249.0, $248.0,247.0,246.0,245.0,244.0,243.0,242.0,241.0,240.0,230.0,220.0$, 210.0, $200.0 \mathrm{ug} / \mathrm{mL}$.

Para a própolis Scaptotrigona sp., foram testadas as concentrações: $400.0,399.0,398.0,397.0,396.0,395.0,394.0,393.0,392.0,391.0,390.0$, $380.0,370.0,360.0,350.0 \mu \mathrm{g} / \mathrm{mL}$. 
Para, a própolis da abelha Melipona quadrifasciata, foram testadas as concentrações: 400.0, 399.0, 398.0, 397.0, 396.0, 395.0, 394.0, 393.0, 392.0, $391.0,390.0,380.0,370.0,360.0,350.0 \mu \mathrm{g} / \mathrm{mL}$.

\subsection{6- CIM pelo método de microdiluição para Escherichia coli}

Para Escherichia coli foram utilizados os mesmos procedimentos descritos para Pseudomonas aeruginosa (item 3.5.3) para obtenção do inóculo. Foram utilizadas as mesmas amostras de própolis (item 3.5.1), nas seguintes concentrações: 400.0, 350.0, 250.0, 200.0, 190.0, 180.0, 170.0, 160.0, 150.0, $140.0,130.0,120.0,110.0,100.0,90.0,80.0,70.0,60.0$ e $50.0 \mu \mathrm{g} / \mathrm{mL}$.

Para a própolis verde, foram testadas as concentrações: 400.0, 399.0, $398.0,397.0,396.0,395.0,394.0,393.0,392.0,391.0,390.0,380.0,370.0$, 360.0 e $350.0 \mu \mathrm{g} / \mathrm{mL}$.

\section{6- Bioautografia}

Os ensaios antimicrobianos foram realizados no laboratório de Farmacognosia, do departamento de Ciências Farmacêuticas da Faculdade de Ciências Farmacêuticas de Ribeirão Preto - USP, sob supervisão do Prof. Dr. Jairo Kenupp Bastos.

Resumidamente, os extratos que apresentaram atividade antimicrobiana foram analisados através de cromatografia comparativa em camada delgada (CCD), utilizando-se placas de vidro com sílica gel $\mathrm{G}_{60} \mathrm{~F}_{254} 5 \times 20 \mathrm{~cm}$ (Art. 7730-Merck) com a espessura de camada de 0,25 mm. 


\subsection{1- Dissolução dos extratos}

Os extratos foram solubilizados em solventes adequados de acordo com a extração. Neste caso o acetato de etila e o metanol, obtendo-se uma concentração conhecida de $30 \mathrm{mg} / \mathrm{mL}$. Nas placas foram aplicados $8 \mu \mathrm{L}$ do extrato solubilizado com o auxílio de uma microseringa graduada.

\subsection{2- Microorganismos indicadores}

Para revelação das placas foram utilizados os seguintes microrganismos indicadores Micrococcus luteus (ATCC 9341), Staphylococcus aureus (ATCC 25923), Escherichia coli (ATCC 25922) e a Pseudomonas aeruginosa (ATCC 14885). Eles foram replicados em tubo de ensaio contendo TSA e incubadas em estufa a $37^{\circ} \mathrm{C}$ por 24 horas.

Utilizando uma alça de platina esterilizada o microrganismo indicador foi transferido para tubo contendo $5 \mathrm{~mL}$ de solução salina, a qual foi padronizada comparativamente com tubo 0,5 da escala de MacFarland $(0,05 \mathrm{~mL}$ de cloreto de bário a 1,0\% + 9,95 mL de ácido sulfúrico a 1,0\%). Diluições sucessivas foram realizadas até a obtenção de um inóculo de $10^{7}$ células $/ \mathrm{mL}$. A suspensão obtida foi adicionada ao meio Müeller Hinton na proporção de 2 \%, obtendo-se o inóculo. Este foi mantido em banho Maria a $50^{\circ} \mathrm{C}$ até o momento do uso.

\subsection{3- Detecção da atividade antimicrobiana}

As placas cromatográficas, após eluição, foram cuidadosamente secas e as substâncias eluídas foram observadas sob luz ultravioleta (UV) a 254 nm e a $366 \mathrm{~nm}$. 
Sobre as placas, com o auxílio de uma pipeta esterilizada, foi adicionado, lentamente, 20 mL do inóculo ( meio Mülller Hinton).

Aos controles positivos de inibição do crescimento foram aplicados, depois da devida solidificação da placa, $10 \mu \mathrm{g}$ de gentamicina (Laborclin), sendo incubadas a uma temperatura de $37^{\circ} \mathrm{C}$ por 24 horas. Após este período as placas foram reveladas com solução de Ágar $1 \%$ contendo 0,02 \% de cloreto de trifeniltetrazólio (TTC) e reincubadas a $37^{\circ} \mathrm{C}$ por cerca de 30 minutos.

\section{7- Determinação do perfil químico dos extratos hidroalcoólicos das diferentes amostras de própolis}

Os reagentes e os solventes utilizados foram de grau analítico, sendo que para as análises em cromatografia líquida de alta eficiência foram empregados solventes de grau cromatográfico e a água empregada na preparação das soluções foi purificada em sistemas de filtro MILLI-Q-PLUS da MILLIPORE (Bedford, USA).

Todos os solventes e soluções empregados como fases móveis em cromatografia líquida de alta eficiência, foram filtrados em membrana de nitrato de celulose.

A identificação foi realizada comparando-se o tempo de retenção, lambda máximo e a razão das áreas dos picos em 280 e $320 \mathrm{~nm}\left(\mathrm{~A}^{280 / 320}\right)$ de acordo com SOUSA (1999), em cromatografia líquida de alta eficiência utilizando-se três condições diferentes: 
Condição 1: fase estacionária coluna C-18 (CLC-ODS), especificada e como fase móvel gradiente multi-linear.

Condição 2: fase estacionária coluna C-18 (CLC-ODS) e como fase móvel sistema isocrático com 25\% de solução tampão pH 4,0 (93,9\% água + 0,8\% de ácido acético + 0,3\% de acetato de amônio $+5 \%$ de $\mathrm{MeOH}$ ) e 75\% de acetonitrila, fluxo de $1,5 \mathrm{~mL} / \mathrm{min}$.

Condição 3: fase estacionária a coluna $\mathrm{CN}$ e como fase móvel sistema isocrático com $25 \%$ de solução tampão pH 4,0 (93,9\% de água + 0,8\% de ácido acético + 0,3\% de acetato de amônio + 5\% de $\mathrm{MeOH}$ ) e $75 \%$ de acetonitrila, fluxo de $1,5 \mathrm{~mL} / \mathrm{min}$.

Fase móvel: gradiente multi-linear desenvolvido por SOUSA (1999), apresentado na tabela 1:

Tabela 1: Gradiente multi-linear de eluição para análise qualitativa em CLAE de amostras de própolis.

\begin{tabular}{|c|c|c|}
\hline Tempo $(\mathrm{min})$ & Bomba A (\%) & Bomba B (\%) \\
\hline $0-5.0$ & 75 & 25 \\
10.0 & 65 & 35 \\
15.0 & 62 & 38 \\
20.0 & 60 & 40 \\
45.0 & 55 & 45 \\
50.0 & 30 & 70 \\
55.0 & 20 & 80 \\
60.0 & 0 & 100 \\
\hline
\end{tabular}

Bomba A: 93,9 \% água + 0,8 \% de ácido acético + 0,3 \% de ácido de amônio $+5 \%$ de $\mathrm{MeOH}$

Bomba B: acetonitrila

Fluxo: $1 \mathrm{~mL} / \mathrm{min}$

Detecção: UV a $280 \mathrm{~nm}$. 


\section{4- Resultados}

\section{1- CIM para Aspergillus nidulans}

Os resultados do teste de Concentração Inibitória Mínima apresentada nas tabelas 2 e 3 permitem concluir que nenhuma das amostras de própolis apresentou atividade antifúngica frente ao Aspergillus nidulans.

Tabela 2: Diferentes concentrações de própolis testadas frente ao Aspergillus nidulans.

\begin{tabular}{|c|c|c|c|c|}
\hline $\begin{array}{c}\text { Concentrações } \\
\text { testadas } \\
\mathrm{mg} / \mathrm{mL}\end{array}$ & $\begin{array}{c}\text { Scaptotrigona sp. } \\
0.01\end{array} \quad \begin{array}{c}\text { Melipona } \\
\text { compressipes } \\
\text { fasciculata }\end{array}$ & $\begin{array}{c}\text { Apis mellifera } \\
\text { (verde) }\end{array}$ & $\begin{array}{c}\text { Melipona } \\
\text { quadrifasciata }\end{array}$ \\
0.02 & + & + & + & + \\
0.04 & + & + & + & + \\
0.09 & + & + & + & + \\
0.18 & + & + & + & + \\
0.37 & + & + & + & + \\
0.75 & + & + & + & + \\
1.50 & + & + & + & + \\
3.00 & + & + & + & + \\
3.75 & + & + & + & + \\
7.50 & + & + & + & + \\
15.0 & + & + & + & + \\
30,0 & + & + & + & + \\
60,0 & + & + & + & + \\
120,0 & + & + & + & + \\
240,0 & + & + & + & + \\
480,0 & + & + & + & + \\
& + & + & + & + \\
\hline
\end{tabular}

"+" indica o crescimento do microorganismo na concentração correspondente.

"-" significa que o microorganismo indicador não cresceu na concentração correspondente. 
Tabela 3: Diferentes concentrações de própolis testadas frente ao Aspergillus nidulans.

\begin{tabular}{|c|c|c|c|c|c|}
\hline $\begin{array}{c}\text { Concentrações } \\
\text { testadas mg/mL }\end{array}$ & $\begin{array}{c}\text { Tetragonisca } \\
\text { angustula }\end{array}$ & $\begin{array}{c}\text { Plebeia } \\
\text { droryana }\end{array}$ & $\begin{array}{c}\text { Scaptotrigona } \\
\text { bipunctata }\end{array}$ & $\begin{array}{c}\text { Friesiomelitta } \\
\text { varia }\end{array}$ & $\begin{array}{c}\text { Nannotrigona } \\
\text { testaceicornis }\end{array}$ \\
\hline 0.01 & + & + & + & + & + \\
0.02 & + & + & + & + & + \\
0.04 & + & + & + & + & + \\
0.09 & + & + & + & + & + \\
0.18 & + & + & + & + & + \\
0.37 & + & + & + & + & + \\
0.75 & + & + & + & + & + \\
1.50 & + & + & + & + & + \\
3.00 & + & + & + & + & + \\
3.75 & + & + & + & + & + \\
7.50 & + & + & + & + & + \\
15.0 & + & + & + & + & + \\
30,0 & + & + & + & + & + \\
60,0 & + & + & + & + & + \\
120,0 & + & + & + & + & + \\
240,0 & + & + & + & + \\
480,0 & + & + & + & + \\
\hline
\end{tabular}

"+" indica o crescimento do microorganismo na concentração correspondente.

"-“ significa que o microorganismo indicador não cresceu na concentração correspondente. 


\section{2- CIM para Trichophyton rubrum}

Nem todas as amostras de própolis mostraram-se eficazes contra o Trichophyton rubrum, confirmando o estudo de Koc et al., (2005). Eles demonstraram que somente alguns tipos de própolis apresentam ação antifúngica contra as linhagens de Trichophyton rubrum. A concentração inibitória mínima determinada foi $29,5 \mathrm{mg} / \mathrm{mL}$ para a própolis da abelha Scaptotrigona sp. (tabela 4); 29,0mg/mL própolis da abelha Melipona compressipes fasciculata, (tabela 4); $29,5 \mathrm{mg} / \mathrm{mL}$ própolis da abelha Melipona quadrifasciata (tabela 4); 6,5mg/mL para própolis verde (Apis mellifera). A partir destes resultados pode-se afirmar que a eficácia ocorreu na seguinte ordem: Própolis verde (Apis mellifera) > Própolis da abelha Melipona compressipes fasciculata> Própolis da abelha Scaptotrigona sp. e Melipona quadrifasciata testadas frente ao Trichophyton rubrum. Podemos concluir ainda que as própolis das abelhas Tetragonisca angustula (tabela 4), Plebeia droryana, Friesiomelitta varia, Scaptotrigona bipunctata e Nannotrigona testaceicornis (apresentadas na tabela 5) não apresentaram nenhuma atividade frente ao Trichophyton rubrum. 
Tabela 4: Diferentes concentrações de própolis testadas frente ao Trichophyton rubrum.

\begin{tabular}{|c|c|c|c|c|c|c|c|c|c|}
\hline \multicolumn{2}{|c|}{$\begin{array}{c}\text { Scaptotrigona sp. } \\
\mathrm{mg} / \mathrm{mL}\end{array}$} & \multicolumn{2}{|c|}{$\begin{array}{c}\text { Melipona } \\
\text { compressipes } \\
\text { fasciculata }\end{array}$} & \multicolumn{2}{|c|}{$\begin{array}{l}\text { Apis mellifera } \\
\text { (verde) }\end{array}$} & \multicolumn{2}{|c|}{$\begin{array}{c}\text { Melipona } \\
\text { quadrifasciata }\end{array}$} & \multicolumn{2}{|c|}{$\begin{array}{c}\text { Tetragonisca } \\
\text { angustula }\end{array}$} \\
\hline 0.001 & + & 0.001 & + & 0.001 & + & 0.001 & + & 0.001 & + \\
\hline 0.002 & + & 0.002 & + & 0.002 & + & 0.002 & + & 0.002 & + \\
\hline 0.004 & + & 0.004 & + & 0.004 & + & 0.004 & + & 0.004 & + \\
\hline 0.008 & + & 0.008 & + & 0.008 & + & 0.008 & + & 0.008 & + \\
\hline 0.016 & + & 0.016 & + & 0.016 & + & 0.016 & + & 0.016 & + \\
\hline 0.032 & + & 0.032 & + & 0.032 & + & 0.032 & + & 0.032 & + \\
\hline 0.064 & + & 0.064 & + & 0.064 & + & 0.064 & + & 0.064 & + \\
\hline 0,11 & + & 0,11 & + & 0,11 & + & 0,11 & + & 0,11 & + \\
\hline 0.23 & + & 0.23 & + & 0.23 & + & 0.23 & + & 0.23 & + \\
\hline 0.46 & + & 0.46 & + & 0.46 & + & 0.46 & + & 0.46 & + \\
\hline 0.93 & + & 0.93 & + & 0.93 & + & 0.93 & + & 0.93 & + \\
\hline 1.87 & + & 1.87 & + & 1.87 & + & 1.87 & + & 1.87 & + \\
\hline 3.75 & + & 3.75 & + & 3.75 & + & 3.75 & + & 3.75 & + \\
\hline 7.50 & + & 7.50 & + & 7.50 & - & 7.50 & + & 7.50 & + \\
\hline 15.0 & + & 15.0 & + & 15.0 & - & 15.0 & + & 15.0 & + \\
\hline 30.0 & - & 30.0 & - & 30.0 & - & 30.0 & - & 30.0 & + \\
\hline 15.0 & + & 15.0 & + & 3.75 & + & 15.0 & + & 60.0 & + \\
\hline 16.5 & + & 20.0 & + & 4.00 & + & 16.5 & + & 120.0 & + \\
\hline 22.5 & + & 25.0 & + & 4.50 & + & 22.5 & + & 240.0 & + \\
\hline 25.5 & + & 30.0 & - & 5.50 & + & 25.5 & + & 480.0 & + \\
\hline 27.5 & + & 25.0 & + & 7.50 & - & 27.5 & + & & \\
\hline 30.0 & - & 26.0 & + & 5.50 & + & 30.0 & - & & \\
\hline 27.5 & + & 27.0 & + & 6.50 & - & 27.5 & + & & \\
\hline 28.5 & + & 28.0 & + & 7.50 & - & 28.5 & + & & \\
\hline 29.5 & - & 29.0 & - & & & 29.5 & - & & \\
\hline 30.0 & - & 30.0 & - & & & 30.0 & - & & \\
\hline
\end{tabular}

"+" indica o crescimento do microorganismo na concentração correspondente.

"-" significa que o microorganismo indicador não cresceu na concentração correspondente. 
Tabela 5: Diferentes concentrações de própolis testadas frente ao Trichophyton rubrum.

\begin{tabular}{|c|c|c|c|c|c|c|c|}
\hline \multicolumn{2}{|c|}{$\begin{array}{c}\text { Plebeia droryana } \\
\mathrm{mg} / \mathrm{mL}\end{array}$} & \multicolumn{2}{|c|}{ Scaptotrigona bipunctata } & \multicolumn{2}{|c|}{ Friesiomelitta varia } & \multicolumn{2}{|c|}{$\begin{array}{l}\text { Nannotrigona } \\
\text { testaceicornis }\end{array}$} \\
\hline 0.001 & + & 0.001 & + & 0.001 & + & 0.001 & + \\
\hline 0.002 & + & 0.002 & + & 0.002 & + & 0.002 & + \\
\hline 0.004 & + & 0.004 & + & 0.004 & + & 0.004 & + \\
\hline 0.008 & + & 0.008 & + & 0.008 & + & 0.008 & + \\
\hline 0.016 & + & 0.016 & + & 0.016 & + & 0.016 & + \\
\hline 0.032 & + & 0.032 & + & 0.032 & + & 0.032 & + \\
\hline 0.064 & + & 0.064 & + & 0.064 & + & 0.064 & + \\
\hline 0,11 & + & 0,11 & + & 0,11 & + & 0,11 & + \\
\hline 0.23 & + & 0.23 & + & 0.23 & + & 0.23 & + \\
\hline 0.46 & + & 0.46 & + & 0.46 & + & 0.46 & + \\
\hline 0.93 & + & 0.93 & + & 0.93 & + & 0.93 & + \\
\hline 1.87 & + & 1.87 & + & 1.87 & + & 1.87 & + \\
\hline 3.75 & + & 3.75 & + & 3.75 & + & 3.75 & + \\
\hline 7.50 & + & 7.50 & + & 7.50 & + & 7.50 & + \\
\hline 15.0 & + & 15.0 & + & 15.0 & + & 15.0 & + \\
\hline 30.0 & + & 30.0 & + & 30.0 & + & 30.0 & + \\
\hline 60.0 & + & 60.0 & + & 60.0 & + & 60.0 & + \\
\hline 120.0 & + & 120.0 & + & 120.0 & + & 120.0 & + \\
\hline 240.0 & + & 240.0 & + & 240.0 & + & 240.0 & + \\
\hline 480.0 & + & 480.0 & + & 480.0 & + & 480.0 & + \\
\hline
\end{tabular}

"+" indica o crescimento do microorganismo na concentração correspondente.

"-" significa que o microorganismo indicador não cresceu na concentração correspondente. 


\section{3- CIM para Pseudomonas aeruginosa}

Com relação à bactéria Pseudomonas aeruginosa a própolis da abelha Melipona quadrifasciata apresentou melhor atividade antimicrobiana (tabela 6 ) que a própolis verde (tabela 6), sendo que as própolis das abelhas Scaptotrigona sp. (tabela 6), Tetragonisca angustula (tabela 6), Plebeia droryana, Friesiomelitta varia, Nannotrigona testaceicornis e Scaptotrigona bipunctata (apresentadas na tabela 7) não apresentaram nenhuma atividade antimicrobiana. A concentração inibitória mínima determinada foi 199ug/mL para a própolis da abelha Melipona quadrifasciata (tabela 6) e 397ug/mL para própolis da abelha Apis mellifera (verde) (tabela 6). 
Tabela 6: Diferentes concentrações de própolis testadas frente à bactéria Pseudomonas aeruginosa.

\begin{tabular}{|c|c|c|c|c|c|c|c|c|c|c|c|}
\hline \multicolumn{2}{|c|}{$\begin{array}{c}\text { Scaptotrigona sp. } \\
\mu \mathrm{g} / \mathrm{mL}\end{array}$} & \multicolumn{2}{|c|}{$\begin{array}{c}\text { Apis mellifera } \\
\text { (verde) }\end{array}$} & \multicolumn{2}{|c|}{$\begin{array}{c}\text { Apis mellifera } \\
\text { (verde) }\end{array}$} & \multicolumn{2}{|c|}{$\begin{array}{c}\text { Melipona } \\
\text { quadrifasciata }\end{array}$} & \multicolumn{2}{|c|}{$\begin{array}{c}\text { Melipona } \\
\text { quadrifasciata }\end{array}$} & \multicolumn{2}{|c|}{$\begin{array}{c}\text { Tetragonisca } \\
\text { angustula }\end{array}$} \\
\hline 50 & + & 50 & + & 400 & - & 50 & + & 400 & - & 50 & + \\
\hline 60 & + & 60 & + & 350 & + & 60 & + & 190 & + & 60 & + \\
\hline 70 & + & 70 & + & 360 & + & 70 & + & 191 & + & 70 & + \\
\hline 80 & + & 80 & + & 370 & + & 80 & + & 192 & + & 80 & + \\
\hline 90 & + & 90 & + & 380 & + & 90 & + & 193 & + & 90 & + \\
\hline 100 & + & 100 & + & 390 & + & 100 & + & 194 & + & 100 & + \\
\hline 110 & + & 110 & + & 400 & - & 110 & + & 195 & + & 110 & + \\
\hline 120 & + & 120 & + & 390 & + & 120 & + & 196 & + & 120 & + \\
\hline 130 & + & 130 & + & 391 & + & 130 & + & 197 & + & 130 & + \\
\hline 140 & + & 140 & + & 392 & + & 140 & + & 198 & + & 140 & + \\
\hline 150 & + & 150 & + & 393 & + & 150 & + & 199 & - & 150 & + \\
\hline 160 & + & 160 & + & 394 & + & 160 & + & 200 & - & 160 & + \\
\hline 170 & + & 170 & + & 395 & + & 170 & + & & & 170 & + \\
\hline 180 & + & 180 & + & 396 & + & 180 & + & & & 180 & + \\
\hline 190 & + & 190 & + & 397 & - & 190 & + & & & 190 & + \\
\hline 200 & + & 200 & + & 398 & - & 200 & - & & & 200 & + \\
\hline 250 & + & 250 & + & 399 & - & 250 & - & & & 250 & + \\
\hline 350 & + & 350 & + & 400 & - & 350 & - & & & 350 & + \\
\hline 400 & + & & & & & & & & & 400 & + \\
\hline
\end{tabular}

"+" indica o crescimento do microorganismo na concentração correspondente.

"-" significa que o microorganismo indicador não cresceu na concentração correspondente. 
Tabela 7: Diferentes concentrações de própolis da testadas frente à bactéria Pseudomonas aeruginosa.

\begin{tabular}{|c|c|c|c|c|c|c|c|}
\hline & $\begin{array}{l}\text { beia droryana } \\
\mu \mathrm{g} / \mathrm{mL}\end{array}$ & Sca & rigona bipunctata & & iomelitta varia & & $\begin{array}{l}\text { annotrigona } \\
\text { staceicornis }\end{array}$ \\
\hline 50 & + & 50 & + & 50 & + & 50 & + \\
\hline 60 & + & 60 & + & 60 & + & 60 & + \\
\hline 70 & + & 70 & + & 70 & + & 70 & + \\
\hline 80 & + & 80 & + & 80 & + & 80 & + \\
\hline 90 & + & 90 & + & 90 & + & 90 & + \\
\hline 100 & + & 100 & + & 100 & + & 100 & + \\
\hline 110 & + & 110 & + & 110 & + & 110 & + \\
\hline 120 & + & 120 & + & 120 & + & 120 & + \\
\hline 130 & + & 130 & + & 130 & + & 130 & + \\
\hline 140 & + & 140 & + & 140 & + & 140 & + \\
\hline 150 & + & 150 & + & 150 & + & 150 & + \\
\hline 160 & + & 160 & + & 160 & + & 160 & + \\
\hline 170 & + & 170 & + & 170 & + & 170 & + \\
\hline 180 & + & 180 & + & 180 & + & 180 & + \\
\hline 190 & + & 190 & + & 190 & + & 190 & + \\
\hline 200 & + & 200 & + & 200 & + & 200 & + \\
\hline 250 & + & 250 & + & 250 & + & 250 & + \\
\hline 350 & + & 350 & + & 350 & + & 350 & + \\
\hline 400 & + & 400 & + & 400 & + & 400 & + \\
\hline
\end{tabular}

"+" indica o crescimento do microorganismo na concentração correspondente.

"-“ significa que o microorganismo indicador não cresceu na concentração correspondente. 


\section{4- CIM para Micrococcus luteus}

Com relação à bactéria Micrococcus luteus pode-se afirmar que a própolis verde (Apis mellifera) apresentou melhor atividade antimicrobiana (tabela 8), que a própolis da abelha Melipona quadrifasciata (tabela 9) e que a própolis da abelha Scaptotrigona sp. (tabela 8). As própolis das abelhas: Tetragonisca angustula (tabela 8), Plebeia droryana (tabela 8), Scaptotrigona bipunctata (tabela 9), Friesiomelitta varia (tabela 9) e Nannotrigona testaceicornis (tabela 9) não apresentaram nenhuma atividade antimicrobiana. Portanto, a eficácia ocorreu na seguinte ordem: própolis verde > própolis da abelha Melipona quadrifasciata > própolis da abelha Scaptotrigona sp. A concentração inibitória mínima foi $187 \mathrm{ug} / \mathrm{mL}$ própolis da abelha Apis mellifera (verde) (tabela 8), 237ug/mL própolis da abelha Melipona quadrifasciata (tabela 9) e 346ug/mL própolis da abelha Scaptotrigona sp. (tabela 8). 
Tabela 8: Diferentes concentrações de própolis da testadas frente à bactéria Micrococcus luteus.

\begin{tabular}{|c|c|c|c|c|c|c|c|c|c|c|c|}
\hline \multicolumn{2}{|c|}{$\begin{array}{c}\text { Scaptotrigona sp. } \\
\mu \mathrm{g} / \mathrm{mL}\end{array}$} & \multicolumn{2}{|c|}{ Scaptotrigona sp. } & \multicolumn{2}{|c|}{$\begin{array}{c}\text { Apis mellifera } \\
\text { (verde) }\end{array}$} & \multicolumn{2}{|c|}{$\begin{array}{l}\text { Apis mellifera } \\
\text { (verde) }\end{array}$} & \multicolumn{2}{|c|}{ Plebeia droryana } & \multicolumn{2}{|c|}{$\begin{array}{c}\text { Tetragonisca } \\
\text { angustula }\end{array}$} \\
\hline 50 & + & 260 & + & 50 & + & 180 & + & 50 & + & 50 & + \\
\hline 60 & + & 270 & + & 60 & + & 181 & + & 60 & + & 60 & + \\
\hline 70 & + & 280 & + & 70 & + & 182 & + & 70 & + & 70 & + \\
\hline 80 & + & 290 & + & 80 & + & 183 & + & 80 & + & 80 & + \\
\hline 90 & + & 300 & + & 90 & + & 184 & + & 90 & + & 90 & + \\
\hline 100 & + & 310 & + & 100 & + & 185 & + & 100 & + & 100 & + \\
\hline 110 & + & 320 & + & 110 & + & 186 & + & 110 & + & 110 & + \\
\hline 120 & + & 330 & + & 120 & + & 187 & - & 120 & + & 120 & + \\
\hline 130 & + & 340 & + & 130 & + & 188 & - & 130 & + & 130 & + \\
\hline 140 & + & 350 & - & 140 & + & 189 & - & 140 & + & 140 & + \\
\hline 150 & + & 340 & + & 150 & + & 190 & - & 150 & + & 150 & + \\
\hline 160 & + & 341 & + & 160 & + & & & 160 & + & 160 & + \\
\hline 170 & + & 342 & + & 170 & + & & & 170 & + & 170 & + \\
\hline 180 & + & 343 & + & 180 & + & & & 180 & + & 180 & + \\
\hline 190 & + & 344 & + & 190 & - & & & 190 & + & 190 & + \\
\hline 200 & + & 345 & + & 200 & - & & & 200 & + & 200 & + \\
\hline 250 & + & 346 & - & 250 & - & & & 250 & + & 250 & + \\
\hline 350 & - & 347 & - & 350 & - & & & 350 & + & 350 & + \\
\hline 400 & - & 348 & - & 400 & - & & & 400 & + & 400 & + \\
\hline \multirow[t]{2}{*}{250} & + & 349 & - & & & & & & & & \\
\hline & & 350 & - & & & & & & & & \\
\hline
\end{tabular}

"+" indica o crescimento do microorganismo na concentração correspondente.

"-“" significa que o microorganismo indicador não cresceu na concentração correspondente. 
Tabela 9: Diferentes concentrações de própolis da testadas frente à bactéria Micrococcus luteus.

\begin{tabular}{|c|c|c|c|c|c|c|c|c|c|}
\hline \multicolumn{2}{|c|}{$\begin{array}{c}\text { Melipona } \\
\text { quadrifasciata }\end{array}$} & \multicolumn{2}{|c|}{$\begin{array}{c}\text { Melipona } \\
\text { quadrifasciata }\end{array}$} & \multicolumn{2}{|c|}{$\begin{array}{c}\text { Scaptotrigona } \\
\text { bipunctata }\end{array}$} & \multicolumn{2}{|c|}{ Friesiomelitta varia } & \multicolumn{2}{|c|}{$\begin{array}{l}\text { Nannotrigona } \\
\text { testaceicornis }\end{array}$} \\
\hline 50 & + & 200 & + & 50 & + & 50 & + & 50 & + \\
\hline 60 & + & 210 & + & 60 & + & 60 & + & 60 & + \\
\hline 70 & + & 220 & + & 70 & + & 70 & + & 70 & + \\
\hline 80 & + & 230 & + & 80 & + & 80 & + & 80 & + \\
\hline 90 & + & 240 & - & 90 & + & 90 & + & 90 & + \\
\hline 100 & + & 250 & - & 100 & + & 100 & + & 100 & + \\
\hline 110 & + & 230 & + & 110 & + & 110 & + & 110 & + \\
\hline 120 & + & 231 & + & 120 & + & 120 & + & 120 & + \\
\hline 130 & + & 232 & + & 130 & + & 130 & + & 130 & + \\
\hline 140 & + & 233 & + & 140 & + & 140 & + & 140 & + \\
\hline 150 & + & 234 & + & 150 & + & 150 & + & 150 & + \\
\hline 160 & + & 235 & + & 160 & + & 160 & + & 160 & + \\
\hline 170 & + & 236 & + & 170 & + & 170 & + & 170 & + \\
\hline 180 & + & 237 & - & 180 & + & 180 & + & 180 & + \\
\hline 190 & + & 238 & - & 190 & + & 190 & + & 190 & + \\
\hline 200 & + & 239 & - & 200 & + & 200 & + & 200 & + \\
\hline 250 & - & 240 & - & 250 & + & 250 & + & 250 & + \\
\hline 350 & - & & & 350 & + & 350 & + & 350 & + \\
\hline 400 & - & & & 400 & + & 400 & + & 400 & + \\
\hline
\end{tabular}

"+" indica o crescimento do microorganismo na concentração correspondente.

"-“ significa que o microorganismo indicador não cresceu na concentração correspondente. 


\section{5- CIM para Staphylococcus aureus}

Em Staphylococcus aureus a eficácia ocorre na seguinte ordem: própolis verde (Apis mellifera) > própolis Melipona quadrifasciata > própolis da abelha Scaptotrigona sp. As própolis das abelhas Tetragonisca angustula (tabela 10), Plebeia droryana (tabela 11), Scaptotrigona bipunctata (tabela 11), Friesiomelitta varia (tabela 11) e Nannotrigona testaceicornis (tabela 10) não apresentaram atividade antimicrobiana, confirmando os estudos feitos por Marcucci (1996). A concentração inibitória mínima foi 249 ug/mL para própolis verde (Apis mellifera) (tabela 10); 397ug/mL Melipona quadrifasciata (tabela 11) e 399ug/mL própolis da abelha Scaptotrigona sp. (tabela 10). 
Tabela 10: Diferentes concentrações de própolis da testadas frente à bactéria Staphylococcus aureus.

\begin{tabular}{|c|c|c|c|c|c|c|c|c|c|c|c|}
\hline \multicolumn{2}{|c|}{$\begin{array}{c}\text { Scaptotrigona sp. } \\
\mu \mathrm{g} / \mathrm{mL}\end{array}$} & \multicolumn{2}{|c|}{ Scaptotrigona sp. } & \multicolumn{2}{|c|}{$\begin{array}{c}\text { Apis mellifera } \\
\text { (verde) }\end{array}$} & \multicolumn{2}{|c|}{$\begin{array}{c}\text { Apis mellifera } \\
\text { (verde) }\end{array}$} & \multicolumn{2}{|c|}{$\begin{array}{c}\text { Tetragonisca } \\
\text { angustula }\end{array}$} & \multicolumn{2}{|c|}{$\begin{array}{l}\text { Nannotrigona } \\
\text { testaceicornis }\end{array}$} \\
\hline 50 & + & 400 & - & 50 & + & 200 & + & 50 & + & 50 & + \\
\hline 60 & + & 350 & + & 60 & + & 210 & + & 60 & + & 60 & + \\
\hline 70 & + & 360 & + & 70 & + & 220 & + & 70 & + & 70 & + \\
\hline 80 & + & 370 & + & 80 & + & 230 & + & 80 & + & 80 & + \\
\hline 90 & + & 380 & + & 90 & + & 240 & + & 90 & + & 90 & + \\
\hline 100 & + & 390 & + & 100 & + & 250 & - & 100 & + & 100 & + \\
\hline 110 & + & 400 & - & 110 & + & 240 & + & 110 & + & 110 & + \\
\hline 120 & + & 390 & + & 120 & + & 241 & + & 120 & + & 120 & + \\
\hline 130 & + & 391 & + & 130 & + & 242 & + & 130 & + & 130 & + \\
\hline 140 & + & 392 & + & 140 & + & 243 & + & 140 & + & 140 & + \\
\hline 150 & + & 393 & + & 150 & + & 244 & + & 150 & + & 150 & + \\
\hline 160 & + & 394 & + & 160 & + & 245 & + & 160 & + & 160 & + \\
\hline 170 & + & 395 & + & 170 & + & 246 & + & 170 & + & 170 & + \\
\hline 180 & + & 396 & + & 180 & + & 247 & + & 180 & + & 180 & + \\
\hline 190 & + & 397 & + & 190 & + & 248 & + & 190 & + & 190 & + \\
\hline 200 & + & 398 & + & 200 & + & 249 & - & 200 & + & 200 & + \\
\hline 250 & + & 399 & - & 250 & - & 250 & - & 250 & + & 250 & + \\
\hline 350 & + & 400 & - & 350 & - & & & 350 & + & 350 & + \\
\hline & & & & 400 & - & & & 400 & + & 400 & + \\
\hline
\end{tabular}

"+" indica o crescimento do microorganismo na concentração correspondente.

"-“ significa que o microorganismo indicador não cresceu na concentração correspondente. 
Tabela 11: Diferentes concentrações de própolis da testadas frente à bactéria Staphylococcus aureus.

\begin{tabular}{|c|c|c|c|c|c|c|c|c|c|}
\hline \multicolumn{2}{|c|}{$\begin{array}{c}\text { Melipona } \\
\text { quadrifasciata } \\
\mu \mathrm{g} / \mathrm{mL}\end{array}$} & \multicolumn{2}{|c|}{$\begin{array}{c}\text { Melipona } \\
\text { quadrifasciata }\end{array}$} & \multicolumn{2}{|c|}{ Plebeia droryana } & \multicolumn{2}{|c|}{$\begin{array}{c}\text { Scaptotrigona } \\
\text { bipunctata }\end{array}$} & \multicolumn{2}{|c|}{ Friesiomelitta varia } \\
\hline 50 & + & 400 & - & 50 & + & 50 & + & 50 & + \\
\hline 60 & + & 350 & + & 60 & + & 60 & + & 60 & + \\
\hline 70 & + & 360 & + & 70 & + & 70 & + & 70 & + \\
\hline 80 & + & 370 & + & 80 & + & 80 & + & 80 & + \\
\hline 90 & + & 380 & + & 90 & + & 90 & + & 90 & + \\
\hline 100 & + & 390 & + & 100 & + & 100 & + & 100 & + \\
\hline 110 & + & 400 & - & 110 & + & 110 & + & 110 & + \\
\hline 120 & + & 390 & + & 120 & + & 120 & + & 120 & + \\
\hline 130 & + & 391 & + & 130 & + & 130 & + & 130 & + \\
\hline 140 & + & 392 & + & 140 & + & 140 & + & 140 & + \\
\hline 150 & + & 393 & + & 150 & + & 150 & + & 150 & + \\
\hline 160 & + & 394 & + & 160 & + & 160 & + & 160 & + \\
\hline 170 & + & 395 & + & 170 & + & 170 & + & 170 & + \\
\hline 180 & + & 396 & + & 180 & + & 180 & + & 180 & + \\
\hline 190 & + & 397 & - & 190 & + & 190 & + & 190 & + \\
\hline 200 & + & 398 & - & 200 & + & 200 & + & 200 & + \\
\hline 250 & + & 399 & - & 250 & + & 250 & + & 250 & + \\
\hline \multirow[t]{2}{*}{350} & + & 400 & - & 350 & + & 350 & + & 350 & + \\
\hline & & & & 400 & + & 400 & + & 400 & + \\
\hline
\end{tabular}

"+" indica o crescimento do microorganismo na concentração correspondente.

"-" significa que o microorganismo indicador não cresceu na concentração correspondente. 


\section{6- CIM para Escherichia coli}

Em Escherichia coli pode-se afirmar que a própolis que apresentou melhor atividade antimicrobiana foi à própolis verde (Apis mellifera) sendo que a concentração inibitória mínima foi $396 \mathrm{ug} / \mathrm{mL}$ (tabela 12). A própolis da abelha Scaptotrigona sp. também apresentou atividade antimicrobiana, sendo que a concentração inibitória mínima foi 399ug/mL (tabela 12).

As própolis das abelhas: Melipona quadrifasciata, Tetragonisca angustula, Plebeia droryana, Scaptotrigona bipunctata, Friesiomelitta varia e Nannotrigona testaceicornis não apresentaram atividade antibacteriana. 
Tabela 12: Diferentes concentrações de própolis da testadas frente à bactéria Escherichia coli.

\begin{tabular}{|c|c|c|c|c|c|c|c|c|c|}
\hline \multicolumn{2}{|c|}{$\begin{array}{c}\text { Scaptotrigona } \\
\text { sp. } \\
\mu \mathrm{g} / \mathrm{mL}\end{array}$} & \multicolumn{2}{|c|}{ Scaptotrigona sp. } & \multicolumn{2}{|c|}{$\begin{array}{c}\text { Apis mellifera } \\
\text { (verde) }\end{array}$} & \multicolumn{2}{|c|}{$\begin{array}{c}\text { Apis mellifera } \\
\text { (verde) }\end{array}$} & \multicolumn{2}{|c|}{$\begin{array}{c}\text { Melipona } \\
\text { quadrifasciata }\end{array}$} \\
\hline 50 & + & 400 & - & 50 & + & 400 & - & 50 & + \\
\hline 60 & + & 350 & + & 60 & + & 350 & + & 60 & + \\
\hline 70 & + & 360 & + & 70 & + & 360 & + & 70 & + \\
\hline 80 & + & 370 & + & 80 & + & 370 & + & 80 & + \\
\hline 90 & + & 380 & + & 90 & + & 380 & + & 90 & + \\
\hline 100 & + & 390 & + & 100 & + & 390 & + & 100 & + \\
\hline 110 & + & 400 & - & 110 & + & 400 & - & 110 & + \\
\hline 120 & + & 390 & + & 120 & + & 390 & + & 120 & + \\
\hline 130 & + & 391 & + & 130 & + & 391 & + & 130 & + \\
\hline 140 & + & 392 & + & 140 & + & 392 & + & 140 & + \\
\hline 150 & + & 393 & + & 150 & + & 393 & + & 150 & + \\
\hline 160 & + & 394 & + & 160 & + & 394 & + & 160 & + \\
\hline 170 & + & 395 & + & 170 & + & 395 & + & 170 & + \\
\hline 180 & + & 396 & + & 180 & + & 396 & - & 180 & + \\
\hline 190 & + & 397 & + & 190 & + & 397 & - & 190 & + \\
\hline 200 & + & 398 & + & 200 & + & 398 & - & 200 & + \\
\hline 250 & + & 399 & - & 250 & + & 399 & - & 250 & + \\
\hline 350 & + & 400 & - & 350 & + & 400 & - & $\begin{array}{l}350 \\
400\end{array}$ & $\begin{array}{l}+ \\
+\end{array}$ \\
\hline
\end{tabular}

"+" indica o crescimento do microorganismo na concentração correspondente.

"-" significa que o microorganismo indicador não cresceu na concentração correspondente. 
Tabela 13: Diferentes concentrações de própolis da testadas frente à bactéria Escherichia coli.

\begin{tabular}{|c|c|c|c|c|c|c|c|c|c|}
\hline \multicolumn{2}{|c|}{$\begin{array}{c}\text { Tetragonisca } \\
\text { angustula } \\
\mu \mathrm{g} / \mathrm{mL}\end{array}$} & \multicolumn{2}{|c|}{$\begin{array}{l}\text { Plebeia } \\
\text { droryana }\end{array}$} & \multicolumn{2}{|c|}{$\begin{array}{c}\text { Scaptotrigona } \\
\text { bipunctata }\end{array}$} & \multicolumn{2}{|c|}{$\begin{array}{c}\text { Friesiomelitta } \\
\text { varia }\end{array}$} & \multicolumn{2}{|c|}{$\begin{array}{l}\text { Nannotrigona } \\
\text { testaceicornis }\end{array}$} \\
\hline 50 & + & 50 & + & 50 & + & 50 & + & 50 & + \\
\hline 60 & + & 60 & + & 60 & + & 60 & + & 60 & + \\
\hline 70 & + & 70 & + & 70 & + & 70 & + & 70 & + \\
\hline 80 & + & 80 & + & 80 & + & 80 & + & 80 & + \\
\hline 90 & + & 90 & + & 90 & + & 90 & + & 90 & + \\
\hline 100 & + & 100 & + & 100 & + & 100 & + & 100 & + \\
\hline 110 & + & 110 & + & 110 & + & 110 & + & 110 & + \\
\hline 120 & + & 120 & + & 120 & + & 120 & + & 120 & + \\
\hline 130 & + & 130 & + & 130 & + & 130 & + & 130 & + \\
\hline 140 & + & 140 & + & 140 & + & 140 & + & 140 & + \\
\hline 150 & + & 150 & + & 150 & + & 150 & + & 150 & + \\
\hline 160 & + & 160 & + & 160 & + & 160 & + & 160 & + \\
\hline 170 & + & 170 & + & 170 & + & 170 & + & 170 & + \\
\hline 180 & + & 180 & + & 180 & + & 180 & + & 180 & + \\
\hline 190 & + & 190 & + & 190 & + & 190 & + & 190 & + \\
\hline 200 & + & 200 & + & 200 & + & 200 & + & 200 & + \\
\hline 250 & + & 250 & + & 250 & + & 250 & + & 250 & + \\
\hline 350 & + & 350 & + & 350 & + & 350 & + & 350 & + \\
\hline 400 & + & 400 & + & 400 & + & 400 & + & 400 & + \\
\hline
\end{tabular}

"+" indica o crescimento do microorganismo na concentração correspondente.

"-“ significa que o microorganismo indicador não cresceu na concentração correspondente. 


\section{7- CIM para antibiótico padrão}

Para determinar a CIM foram utilizados dois antibióticos diferentes, Estreptomicina (Pseudomonas aeruginosa e Escherichia coli) e Penicilina (Micrococcus luteus e Staphylococcus aureus).

A CIM para antibiótico padrão foi determinada (tabela 14), sendo que a concentração inibitória mínima de Estreptomicina para a bactéria Pseudomonas aeruginosa está entre 2,95 e 1,475 $\mathrm{gg} / \mathrm{mL}$; para Escherichia coli a CIM está entre 0,7375 e 0,3688 $\mu \mathrm{g} / \mathrm{mL}$. A CIM de Penicilina para as bactérias Micrococcus luteus e Staphylococcus aureus está entre: 5,90 e 2,95 $\mu \mathrm{g} / \mathrm{mL}$.

Tabela 14: Protocolo de antibiótico padrão para Pseudomonas aeruginosa, Escherichia coli, Micrococcus luteus e Staphylococcus aureus.

\begin{tabular}{|c|c|c|c|c|}
\hline $\begin{array}{c}\text { Concentrações de } \\
\text { Antibióticos } \mu \mathrm{g} / \mathrm{mL}\end{array}$ & $\begin{array}{c}\text { Pseudomonas } \\
\text { aeruginosa } \\
\text { (Estreptomicina) }\end{array}$ & $\begin{array}{c}\text { Escherichia coli } \\
\text { (Estreptomicina) }\end{array}$ & $\begin{array}{c}\text { Micrococcus } \\
\text { luteus } \\
\text { (Penicilina) }\end{array}$ & $\begin{array}{c}\text { Staphylococcus } \\
\text { aureus } \\
\text { (Penicilina) }\end{array}$ \\
\hline 5,90 & - & - & - & - \\
2,95 & - & - & + & + \\
1,475 & + & - & + & + \\
0,7375 & + & + & + & + \\
0,3688 & + & + & + & + \\
0,1844 & + & + & + & + \\
0,0922 & + & + & + & + \\
0,0461 & + & + & + & + \\
0,0230 & + & + & + & + \\
0,0115 & + & + & + & + \\
\hline
\end{tabular}

\footnotetext{
"+" indica o crescimento do microorganismo na concentração correspondente.

"_" significa que o microorganismo indicador não cresceu na concentração correspondente.
} 
Para verificarmos se as amostras de própolis apresentaram atividade fungicida, fungiostática, bactericida ou bacteriostática, os microorganismos inibidos, foram transferidos para placa de Petri com meios adequados e reincubados em estufa (item 3.4.1, 3.4.2, 3.6.2), sendo que nenhum dos microorganismos testados apresentou crescimento. Isso sugere que as amostras de própolis apresentaram atividade fungicida e bactericida.

Avaliando o perfil cromatográfico obtido da amostra de própolis verde apresentado na figura 1, nota-se a presença de quatro componentes majoritários com distintos níveis de polaridade. Segundo Gregório (2003), os picos detectados em torno de 5 minutos podem ser atribuídos aos ácidos cafeico e cumárico. Os componentes detectados em 25 e 55 minutos são os ácidos 3-prenil-p-cumárico e 3,5 diprenil-p-cumárico, respectivamente. Além disso, observa-se a presença de compostos minoritários pertencentes à classe dos flavonóides entre 30 e 40 minutos.

Os perfis cromatográficos obtidos das amostras de própolis de origem indígena apresentados nas figuras 2, 3 e 4, são complexos e apresentam componentes com polaridades distintas. Tendo em vista o detector utilizado (UV), pode-se afirmar que os componentes que foram detectados apresentam ligações duplas conjugadas e/ou a presença de anéis aromáticos. Possilvelmente esses componentes podem ser derivados de ácidos fenólicos, fenilpropanóides ou flavonóides. Todavia, há a necessidade de utilizar métodos analíticos e eletroscópicos visando atribuir nomes, classes e estruturas químicas dos principais componentes presentes nos diferentes tipos de própolis. 
As figuras a seguir ilustram os cromatogramas das análises em cromatografia líquida de alta eficiência dos extratos hidroalcoólicos das amostras de própolis detecção de $280 \mathrm{~nm}$.

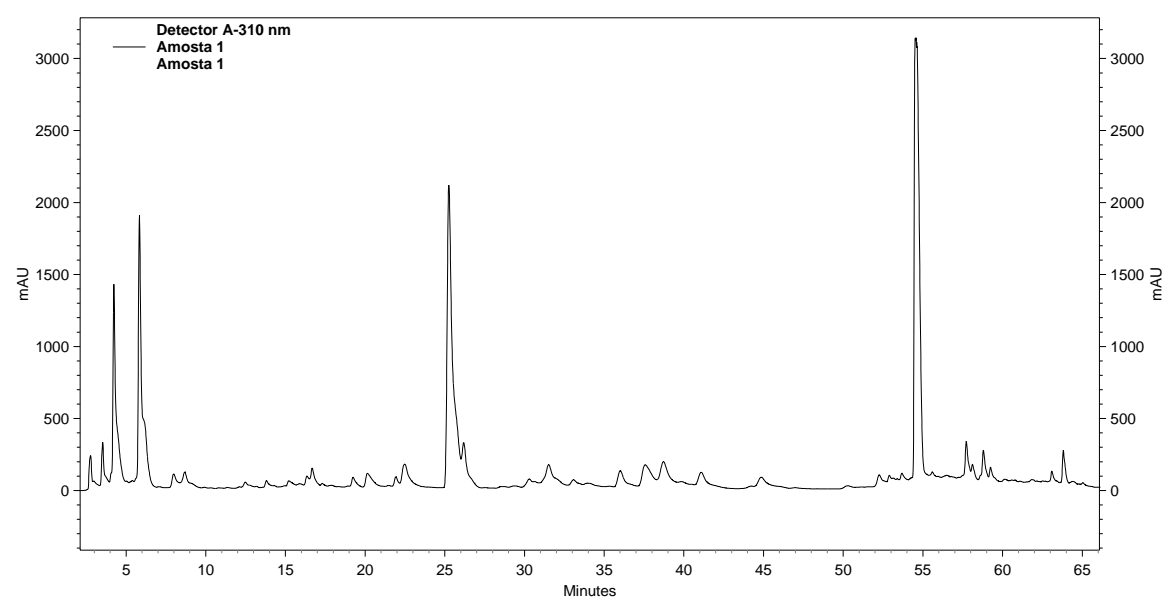

FIGURA 1- Cromatograma do extrato hidroalcoólico da própolis verde (Apis mellifera), coletada em janeiro de 2005, detecção em 280nm.

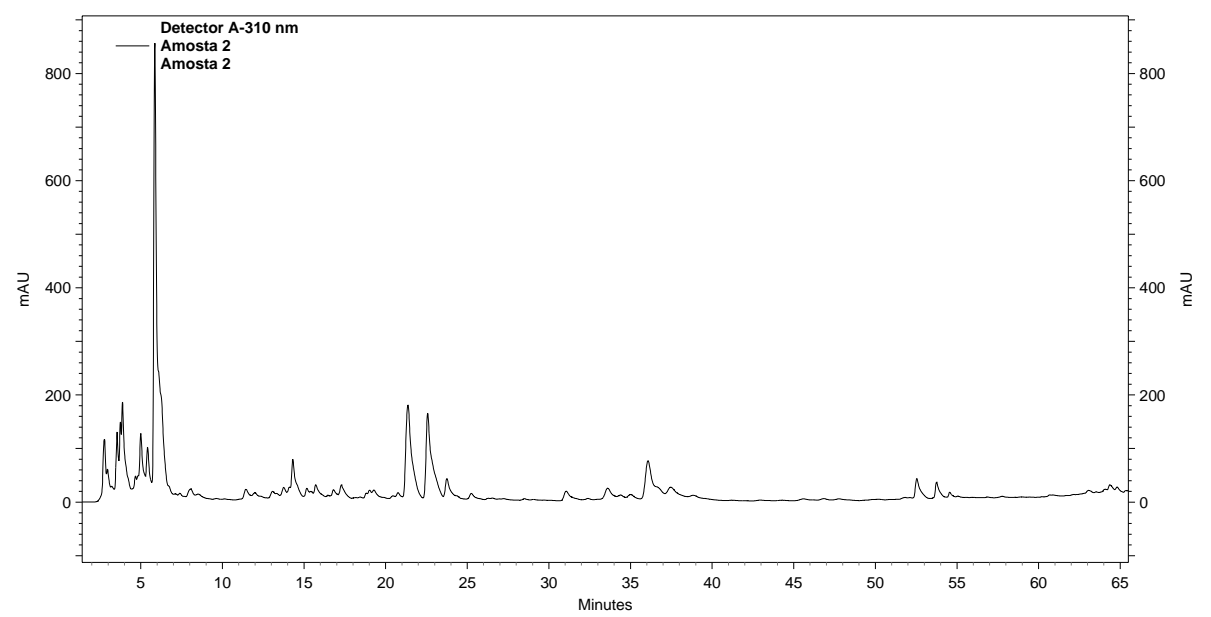

FIGURA 2- Cromatograma do extrato hidroalcoólico da própolis da abelha indígena Melipona quadrifasciata, coletada em janeiro de 2005, detecção em $280 \mathrm{~nm}$. 


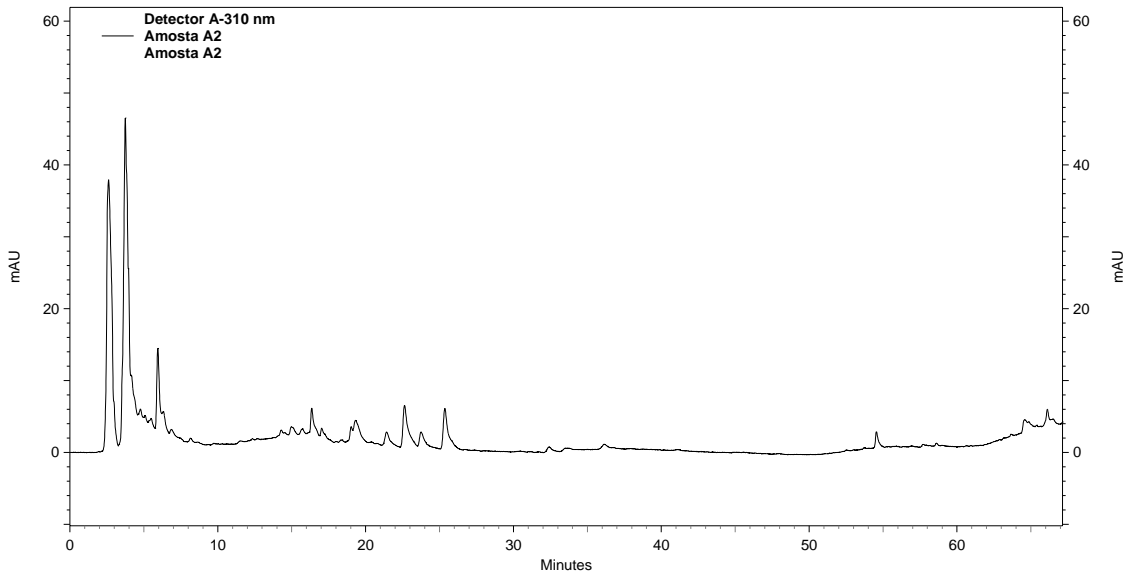

FIGURA 3- Cromatograma do extrato hidroalcoólico da própolis da abelha indígena Scaptotrigona sp., coletada em janeiro de 2005, detecção em 280 nm.

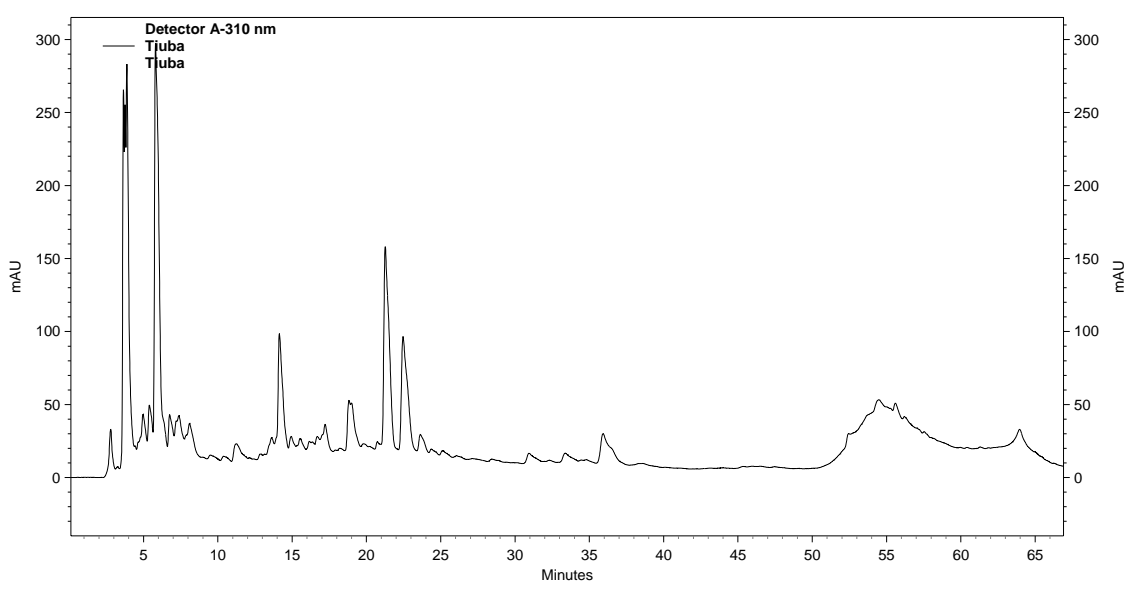

FIGURA 4- Cromatograma do extrato hidroalcoólico da própolis da abelha indígena Melipona compressipes fasciculata, coletada em janeiro de 2005, detecção em 280 nm.

\section{8- Avaliação da atividade antibacteriana}

A partir dos resultados alcançados por cromatografia de camada delgada comparativa (Bioautografia), pode-se afirmar que as amostras de própolis apresentaram perfil cromatográfico e atividade antibacteriana diferentes, respectivamente. Com relação à bactéria Micrococcus luteus, 
apresentadas nas figuras 5 e 6, pode-se constatar que a própolis verde apresentou melhor atividade antibacteriana que as própolis das abelhas Melipona quadrifasciata e Scaptotrigona sp.

Nas figuras 7 e 8 pode-se constatar que em Staphylococcus aureus a própolis verde mostrou-se mais eficaz que as própolis das abelhas Melipona quadrifasciata e Scaptotrigona sp.

Em Escherichia coli, a própolis verde apresentou atividade antibacteriana (figura 9) e a própolis da abelha Melipona quadrifasciata não apresentou nenhuma atividade antibacteriana (figuras 9 e 11).

Em Pseudomonas aeruginosa pode-se observar que a própolis da abelha Melipona quadrifasciata (figuras 12 e 14) apresentou melhor atividade antibacteriana que a própolis verde (figuras 12 e 13) e que a própolis da abelha Scaptotrigona sp. (figuras 12 e 13) não apresentou nenhuma atividade antibacteriana. Podemos constatar ainda que as amostras de própolis apresentam componentes com polaridades distintas, consequentemente atividade antibacteriana diferente.

As figuras a seguir ilustram os resultados obtidos na atividade antibacteriana das diferentes amostras de própolis. 


\subsection{1- Micrococcus luteus}

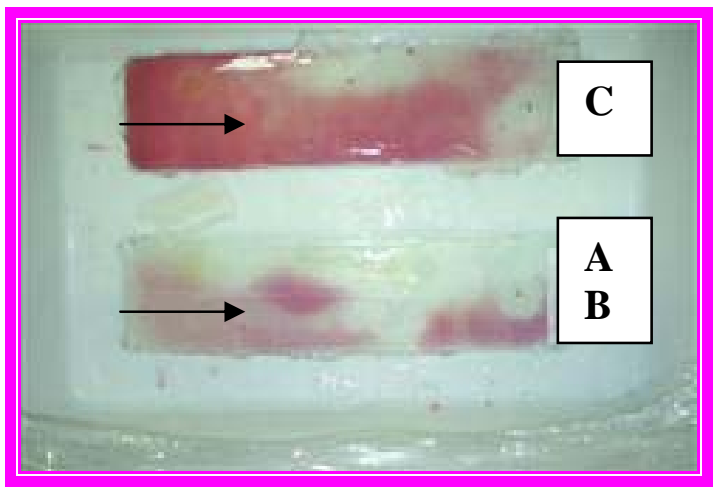

FIGURA 5 - Imagem da placa de cromatografia em camada delgada comparativa utilizada para determinação da atividade antibacteriana dos seguintes extratos: $A=$ própolis verde $B=$ própolis da abelha indígena Scaptotrigona sp.; $\mathrm{C}=$ própolis da abelha Melipona quadrifasciata frente ao Micrococcus luteus por meio de Bioautografia.

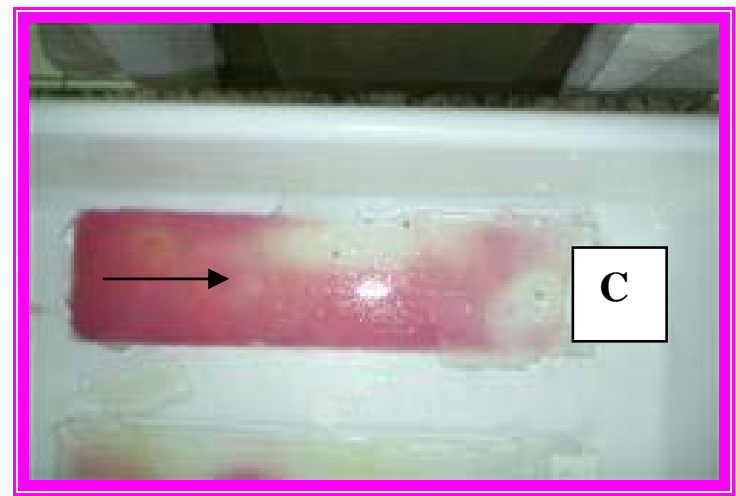

FIGURA 6- Imagem da placa de cromatografia em camada delgada comparativa utilizada para determinação da atividade antibacteriana do extrato de própolis da abelha Melipona quadrifasciata frente ao Micrococcus luteus por meio de Bioautografia. 


\subsection{2- Staphylococcus aureus}

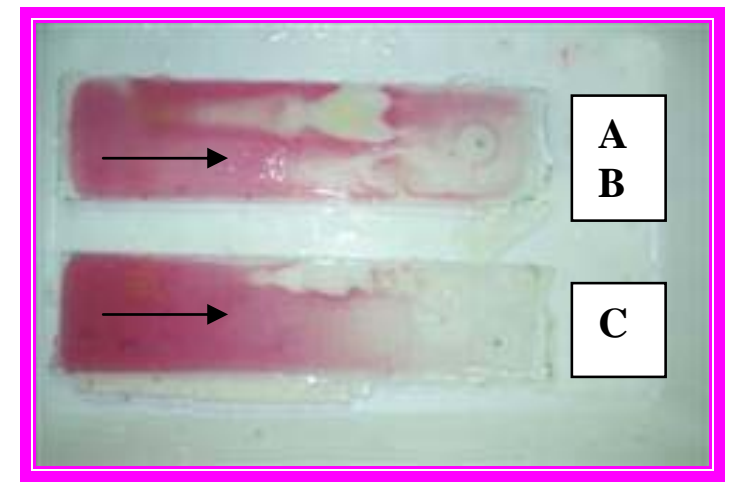

FIGURA 7- Imagem da placa de cromatografia em camada delgada comparativa utilizada para determinação da atividade antibacteriana dos seguintes extratos: $A=$ própolis verde (Apis mellifera); $\mathrm{B}=$ própolis da abelha Scaptotrigona sp.; $\mathrm{C}=$ própolis da abelha Melipona quadrifasciata frente ao Staphylococcus aureus, por meio de Bioautografia.

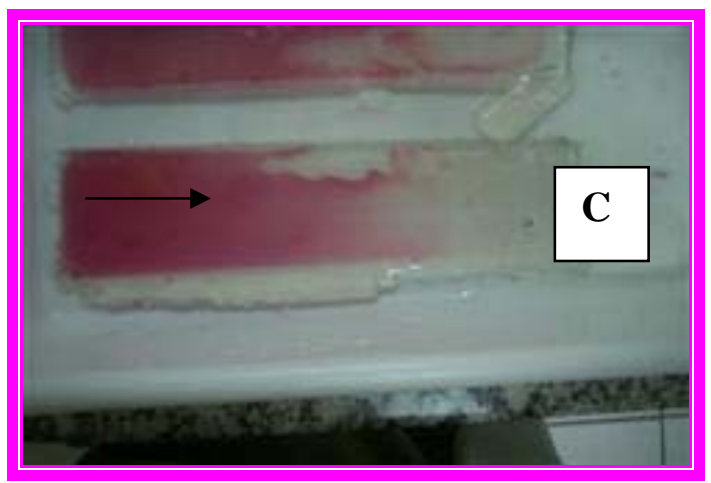

FIGURA 8- Imagem da placa de cromatografia em camada delgada comparativa utilizada para determinação da atividade antibacteriana da própolis da abelha Melipona quadrifasciata frente ao Staphylococcus aureus, por meio de Bioautografia. 


\subsection{3- Escherichia coli}

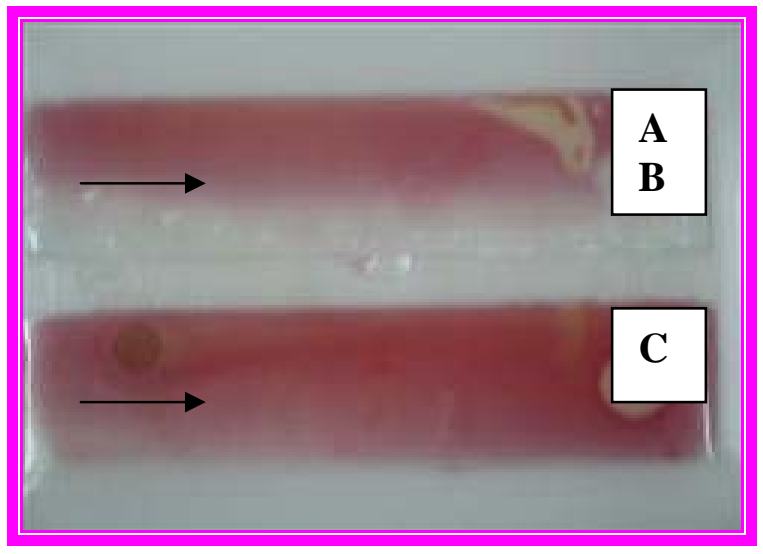

FIGURA 9- Imagem da placa de cromatografia em camada delgada comparativa utilizada para determinação da atividade antibacteriana dos seguintes extratos: $A=$ própolis da abelha Scaptotrigona sp.; $\mathrm{B}=$ própolis verde (Apis mellifera); $\mathrm{C}=$ própolis da abelha Melipona quadrifasciata frente a Escherichia coli, por meio de Bioautografia.

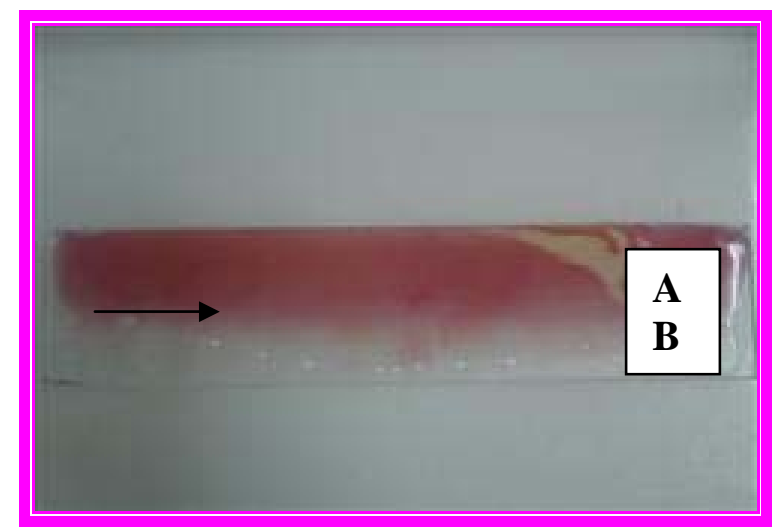

FIGURA 10- Imagem da placa de cromatografia em camada delgada comparativa utilizada para determinação da atividade antibacteriana dos seguintes extratos: $A=$ própolis da abelha Scaptotrigona sp.; $\mathrm{B}=$ própolis verde (Apis mellifera); frente a Escherichia coli, por meio de Bioautografia. 


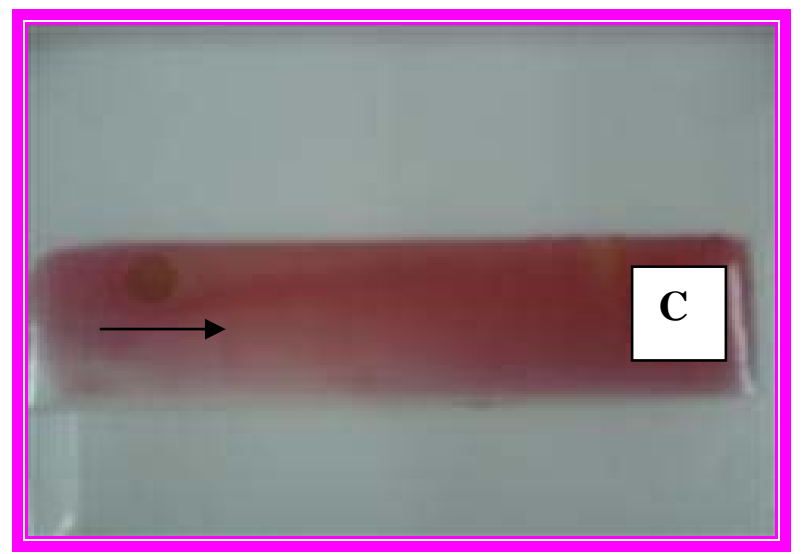

FIGURA 11- Imagem da placa de cromatografia em camada delgada comparativa utilizada para determinação da atividade antibacteriana da própolis da abelha Melipona quadrifasciata frente a Escherichia coli, por meio de Bioautografia.

\subsection{4- Pseudomonas aeruginosa}

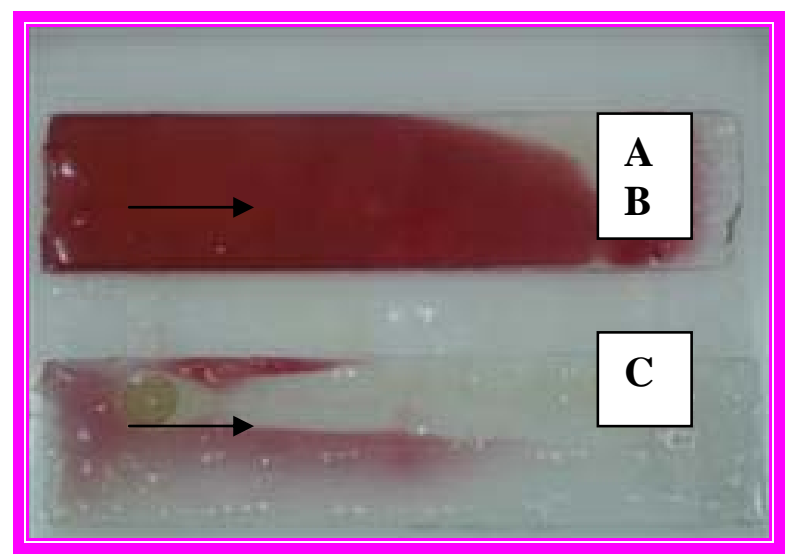

FIGURA 12- Imagem da placa de cromatografia em camada delgada comparativa utilizada para determinação da atividade antibacteriana dos seguintes extratos: $A=$ própolis verde (Apis mellifera); $\mathrm{B}=$ própolis da abelha Scaptotrigona sp.; $\mathrm{C}=$ própolis da abelha Melipona quadrifasciata frente a Pseudomonas aeruginosa, por meio de Bioautografia. 


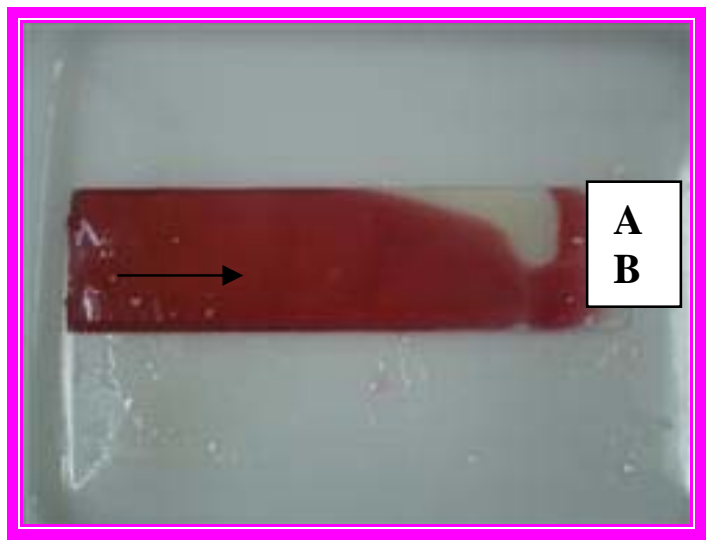

FIGURA 13- Imagem da placa de cromatografia em camada delgada comparativa utilizada para determinação da atividade antibacteriana dos seguintes extratos: $A=$ própolis verde (Apis mellifera); $\mathrm{B}=$ própolis da abelha Scaptotrigona sp. frente a Pseudomonas aeruginosa, por meio de Bioautografia.

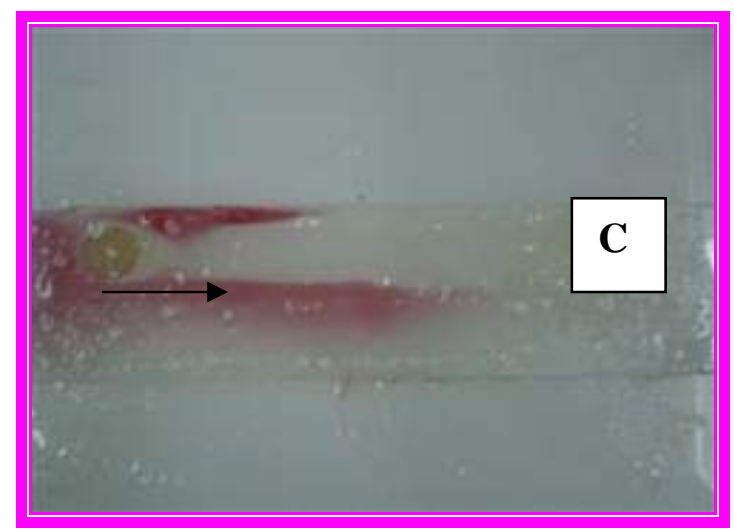

FIGURA 14- Imagem da placa de cromatografia em camada delgada comparativa utilizada para determinação da atividade antibacteriana da própolis da abelha Melipona quadrifasciata frente a Pseudomonas aeruginosa, por meio de Bioautografia. 
Para o controle efetivo dos fungos e bactérias é fundamental o conhecimento sobre a biologia dos patógenos, os seus mecanismos de virulência e os processos de interação com o hospedeiro. Além disso, o relato cada vez mais freqüente de linhagens resistentes aos antifúngicos e antibióticos disponíveis no mercado torna necessárias investigações sobre outras substâncias que atuem de maneira mais específica possível contra fungos e bactérias. Há poucos anos, vários estudos têm sido realizados com relação à susceptibilidade de dermatófitos (in vitro) com drogas antifúngicas e os resultados nos mostram variações consideráveis. Os resultados da susceptibidade antifúngica são influenciados por vários fatores como: pH, tamanho do inóculo, tempo e temperatura da incubação. Com isso, foi estabelecido um protocolo padrão pelo NCCLS, método utilizado neste estudo. O objetivo principal deste trabalho foi avaliar quais tipos de própolis apresentam atividades antifúngicas e antibacterianas frente a alguns microorganismos.

Há uma grande variedade de fármacos com propriedades antifúngicas e antibacterianas, os quais são oferecidos de várias formas farmacêuticas que podem ter uso tópico ou sistêmico.

Antes de prescrevermos o tratamento, é muito importante darmos o diagnóstico correto, e este pode ser confirmado através da presença de determinados microorganismos nos meios de cultura. 
A grande proporção de falhas terapêuticas é devida ao diagnóstico incorreto ou simplesmente a perda de diagnóstico. Por outro lado, a necessidade de estender o tratamento com alto custo às vezes nos leva a desistirmos do tratamento e é sabido que, devido à seleção, cada vez mais aumenta o número de microorganismos resistentes a drogas.

A própolis é uma mistura de substâncias de composição complexa que não apresenta toxidade; tem sido recomendada como monoterapia e/ou associada com outros produtos farmacêuticos devido suas propriedades antibacterianas, antifúngicas, anti-inflamatórias, anti-tumorais, entre outras (Burdok 1998).

A composição química do extrato de própolis ainda é estudada devido a suas variações naturais.

Neste experimento, diferentes tipos de própolis de abelhas africanizadas e de meliponíneos em diferentes concentrações foram estudadas contra: Aspergillus nidulans, Trichophyton rubrum, Pseudomonas aeruginosa, Escherichia coli, Micrococcus luteus e Staphylococcus aureus. O possível mecanismo da ação antibacteriana e antifúngica da própolis foi estudado por Takaisi-Kikuni e Schilcher (1994). Eles observaram a inibição da divisão celular na presença de própolis e isto sugere que a própolis devia agir na inibição da replicação do DNA e indiretamente na divisão celular.

Segundo Ghisalberti (1960) a atividade antifúngica e antibacteriana da própolis é devida à presença de componentes polares, principalmente fenóis (flavonóides, ácidos fenólicos e seus ésteres). 
Os flanonóides são quantativamente e qualitativamente um dos maiores grupos de produtos naturais conhecidos no mundo. Estes são constituintes das células vegetais superiores, atuam em atividades regulatórias de vitaminas liposolúveis e elimanam odores que se comunicam com o meio ambiente (Middleton \& Teramura, 1993). Eles são reconhecidos pelos polinizadores, que contribuem pela dispersão de pólen.

O uso dos flavonóides contra infecções bacterianas e fúngicas tem duas propostas: (1) "matar" as células das bactérias e fungos ou (2) dificultar os efeitos da difusão das toxinas bacterianas (McClure, 1975; Lopes et al., 1998). As maiorias das bactérias que acometem os homens e animais são mortas na presença de flavonóides. Entretanto, esse mecanismo não é totalmente compreendido, mas é sabido que o efeito bactericida dos flavonóides é devido à perturbação metabólica. Os canais de íons, que são componentes tantos de células animais quanto bacterianas, são pontos sensíveis de inibição e provavelmente alvos dos flavonóides. Nas células animais, esses canais são regulados por reações de fosforilação e desforilação. A pesquisa para o uso dos flavonóides para prevenção e cura das doenças já está sendo realizada por vários pesquisadores em alguns países. O uso consciente dessas substâncias é mais comum nos países emergentes do que nas partes industrializadas do mundo.

Neste estudo algumas própolis apresentaram atividades bactericida e fungicida frente a alguns microorganismos. Esses resultados reforçam a 
importância e o potencial do extrato de própolis como tratamento de algumas patologias.

A atividade biológica da própolis indica que esta é a defesa das abelhas contra alguns microorganismos. Nossos resultados, bem como dados da literatura, a ação química e biológica da própolis, não podem apontar uma substância individual ou uma classe particular de substância, pois diferentes combinações de substâncias são essenciais na atividade biológica. Isso é importante para notarmos que todas as investigações da atividade antibacteriana e antifúngica, isoladas da própolis, mostraram que não é um único componente que apresenta atividade maior do que o extrato total (Kujumgiev et al., 1993; Serra Bonvehi et al., 1994).

A maioria dos resultados obtidos são muito animadores, pois podemos utilizar a própolis frente a alguns microorganismos tanto em humanos quanto em animais, podemos ainda fazer uma padronização química e biológica da própolis, apesar dos grandes desafios que temos que superar para que possamos alcançar este objetivo. 


\section{5-Conclusões}

- Em todos os microorganismos testados as própolis das abelhas Tetragonisca angustula, Plebeia droryana, Scaptotrigona bipunctata, Friesiomelitta varia e Nannotrigona testaceicornis, não apresentaram atividade antifúngica nem antibacteriana.

- Nenhuma amostra de própolis apresentou atividade antifúngica frente ao Aspergillus nidulans.

- A linhagem do fungo Trichophyton rubrum mostrou-se sensível a alguns tipos de própolis sendo que a própolis verde foi a mais eficaz.

- Somente alguns tipos de própolis apresentaram atividade antibacteriana. 


\section{6-Perspectivas}

- Experimentos de infecção in vivo através da inoculação de conídios das linhagens em cobaias poderão revelar se as amostras de própolis apresentam as mesmas atividades antifúngicas e antibacterianas que in vitro.

- É possível fazer o isolamento químico das substâncias presentes nas amostras de própolis e avaliar a atividade separadamente, para saber se é apenas uma ou várias classes de substâncias que apresentam atividade frente aos microorganismos. 


\section{7-Referências Bibliográficas}

Abd El Hady, F.K. \& Hegazi, A.G. Egyptian propolis: Chemical composition, antiviral and antimicrobical activities of East Nile Delta propolis. Z. Naturforsch. v.57(3-4), p. 386-394, 2002.

Aga, $\mathrm{H}$. et al., Isolation and identification of anti-microbial compounds in Brasilian propolis. Biosc. Biotech. Biochem. v. 58, p.954-6, 1994.

Aly, S.A \& Elewa, N.A. The effect of Egyptian honeybee propolis on the growh of Aspergillus versicolor and sterigmatocystin biosynthesis in Ras cheese. $\mathbf{J}$. Dairy Res. v.9, p.1-5, 2007.

Amoros, M. et al. Sunergistic effect of flavones and falvonois against Herpes simplex vírus type 1 in cell culture. Comparison with the antiviral activity of propolis. J. Nat. Prot. v.55, p.1732-40, 1992.

Anstey, A. \& Lucke T.W. Philpot C. Tinea cepetis caused by Trychophyton rubrum. Br. J. Dermatol. v.135, p. 113-115, 1996.

Atlas, R.M. Handbook of microbiological media. Edited by Laerence C. Perks. Ed. CRC Press. P.786, 1993.

Bankova, V. et al. A study on flavonoids of propolis. J. Nat. Prod. v.46, p.4714, 1983.

Bankova, V. et al. Propolis produced in Bulgaria and Mongolia: phenolic compounds and plant origin. Apidol., v.23, p.79-85, 1992.

Bankova, V. et al. Seasonal variations of the chemical composition of Brazilian propolis. Apidol., v.29, p.361-7, 1998.

Banskota, A.H. et al.. Chemical constituints of Brazilian propolis and their activities. J. Nat. Prod., Cincinnati, v.61, p.896-900,1998. 
Barberán, F. T. et al. Phytochemical evidence for the botanical origin of tropical propolis from Venezuela. Phytochem., v.34, p.191-6, 1993.

Baron S. Medical Microbiology. $4^{\text {th }}$ ed. Galveston (TX-USA), 1996.

Bastos, E.M.A.F. Origem Botânica e Indicadores de qualidade da "Própolis Verde" Produzida no estado de Minas Gerais, Brasil,137p. Tese Doutorado-Faculdade de Filosofia Ciências e Letras de Ribeirão Preto, Universidade de São Paulo, Ribeirão Preto, 2001.

Boudourova-Krasteva, G.B. et al. Phenolics from Brazilian propolis. Z. Naturforsch. v.52c, p. 676-9, 1997.

Burdok, G.A. Review of the biological properties and toxicity of bee propolis (propolis). Food Chem. Toxicol. v.36, p.347-63, 1998.

Campos, M.G.R. et al. Charactization of lavonoides in three hive products: bee, pollen, propolis and honey. PI. Med., Stuttgart, v.56, p.580-581,1990.

Cervelatti E.P. et al. Electrophoretic molecular kariotype of the dermatophyte Trichophyton rubrum. Gen. Mol. Biol. V.27(1), p.99-112, 2004.

Cheng, P.C. \& Wong, G. Honey bee propolis: prospects in medicine. Bee World, v.77, p.8-15,1996.

Chinelli P.A.V. et al. Dermatophyte agents in the city of São Paulo from 1992 to 2002. Rev. Inst. Med. Trop. S. Paulo v. 45(5), p.259-263, 2003.

Chopra, S. et al. Propolis protects against doxorubicin-induced myocardiopathy in rats. Exp. Mol. Pathol. v.62, p.190-8,1995.

Cizmarick J. \& Lahitova N. Antimutagenicity of propolis. Pharm., v. 53, p.883-4, 1998.

Cook, N.C. \& Samman, S. Flavonoids - Chemistry, metabolism, cardioprotective effects and dietary souces. J. Nutr. Biochem. v.07, p.6676, 1995. 
Costa M. et al. Epidemiologia e etiologia das dermatofitoses em Goiânia, GO, Brasil. Ver. Bras. Med. Trop., v.35(1), p.19-22, 2002.

Debiaggi, M. et al. Effects of propolis flavonoids on virus infectivity and replication. Microbiol., v.13, p. 207-13, 1990.

Dobrowolki, J.W. et al. Antibacterial, antifungal, antiamoebic, antiinflamatory and antipyretic studies on propolis bee products. J. Ethonopharmacol., v.35, p.77-82, 1991.

Fernandes, A. et al. The antibacterial activity of propolis produced y Apis mellifera and Brazilian Stingless, J. Ven. Anim. Tox., v.7(2), 2001.

Foster K.W. et al. Epidemiologic surveillance of cutaneou fungal infection in the United States from 1999 to 2002. Am. Acad. Dermatol. v.50(5), p.748-752, 2004.

Frenkel, K. et al. Inhibition of tumor promoter-mediated process in mouse skin and bovine lens by caffeic acid phenethyl ester. Canc. Res. v.53, p.1255-61, 1993.

Garcia-Vigueira, C.et al. Composition of propolis from two different Spanish regions. Z. Naturforsch., Mainz, v.47, p.634-637, 1992.

Ghisalberti, E. L. Propolis: a review. Bee World v.60, p.50-84, 1960.

Greenaway, W. et al. Identification by gas chromatography-mass spectrometry of 150 compounds in propolis. Z. Naturforsch. v.46c, p 111-21, 1991.

Gregorio, L, E., Influência da sazonalidade na composição polínica, no perfil químico e na atividade antimicrobiana da própolis produzida em Cajuru-SP, 174p. Dissertação (Mestrado)- Faculdade de Ciências Farmacêuticas- Universidade de São Paulo, 2003.

Havsteen, B. Flavonoids, a class of natural products of high pharmacological potency. Biochem. Pharmacol. v.32, p.1141-8, 1983. 
Higashi, K.O \& Castro, S.L. Propolis extracts are effective against Trypanosoma cruzi and have a impact on its interation with host cell. J. Ethnopharmacol. v.43, p. 149-55, 1994.

Hollmam, P.C.H. et al. Analysis and health effects of flavonoids. Food Chem. v.57, p. 43-6,1996.

Ikeno, K. et al. Effects of propolis on dental caries in rats. Caries Res. v.25, p.347-51, 1991.

Ivanoska, M. D. et al. Immunomodulatory action of propolis. V. Anticomplementary activity of a water soluble derivative. $\mathbf{J}$. Ethnopharmacol. v.47, p.135-43, 1995.

Jennings M.B. et al. Study of clinically suspect onychomicosis in a podiatric population, J. Am. Podiatr. Med. Assoc. v.92, p.327-330, 2002.

Kimoto, T. et al. Apoptosis and suppression of tumor growth by artepellin C extracted from Brazilian propolis. Canc. detec. Prev. v.22, p.506-15, 1998.

Kimoto, T. et al. Pulmonary carcinogenisis induced by ferric nitrilotriacetato in mice and protection from it by Brazilian propolis and artepillin C. Virchows Archiv, Heidelberg, v.438(3), p.259-270, 2001a.

Kimoto, T. et al. Apoptosis of human leukemia cells induced by artepillin C, an ative ingredient of Brazilian propolis. Antican. Res., Athens, v.21, p.221228, 2001b.

Koc, A.N. et al. Comparison of in vitro activies of antifungal drugs and ethanolic extract of propolis against Trichophyton rubrum and $T$. mentagrophytes by using a microdiluition assay. Myc.,v.48, p.205-210, 2005.

Koo, M.H \& Park, Y.K,; Investigation of flavonoid aglycones in propolis collected by two different varietes of bees in the same region. Biosc., Biotech. Biochem., Tokyo, v.61(2), p.367-369,1997.

Krol, W. et al. Anti-oxidant property of ethanolic extract of propolis (EEP) as evaluated by inhibiting the chemiluminescencce oxidation of luminol. Biochem. v.21, p.593-7, 1990. 
Kujumgiev, A. et al. Antibacterial activity of propolis, some of its components and their analogs. Pharm., v.48, p.785-786, 1993.

Kwon-Chung KJ \& Bennett JE. Medical mycology. Ed. Lea and Febiger, USA. p.105-161, 1992.

Lopes, N.P. Flavonoids and lignans from Virola surinamensis twings and their in vitro activity against Trypanosoma cruzi . Plant Med. v.64, p.667-668, 1998.

Lu, L.C. et al. Antibacterial activity of propolis against Staphylococcus aureus. J Food Microbiol. vol. 102(2), p.213-20, 2005.

Mahran, G.; Naturals Products. Med. Trad., v.1, p.23, 1977.

Marcucci, M.C. Propolis: chemical composition, biologica properties and therapeutic activity. Apidol., v.26, p.83-99, 1995.

Marcucci, M.C. et al., Propriedades biológicos e terapêuticos dos constituintes químicos da própolis. Quím., São Paulo, v.19, p.529-536,1996.

Marcucci, M.C \& Bankova, V. Chemical composition, plant origin and biological activity of Brazilian propolis. Phytochem., Oxford, v.2, p.115-123, 1999.

Markham, K.R. et al, HPLC and GC-MS identification of major organic constituints in New Zealand propolis. Phytochem., Oxford, v.42, p.205-211, 1996.

Martos, I. et al., Flavonoid composition of Tunisian honeys and propolis. J. Agr. Food Chem., Washington, v.45, n.8, p.2824-2829, 1997.

Matsuno, T. et al. A tumoricidal and antixidant compound isolated from an aqueous extract of propolis. Med. Sci. Res. v.25, p.583-4, 1997.

McClure, J. W. Physiology and functions of flavonoids, Chem., v.18, p.9701055. 1975. 
McGinnis MR , Laboratory handbook of medical mycology. Academic Press, New york, 1980.

Middleton, E.M \& Teramura, A.H. The role of flavonol glycosides and carotinoids in protecting soybean from ultraviolet-B damage. Plant Physiol. v.103, p.741-52, 1993.

Miorin. P.L, Antibacterial activity of honey and propolis from Apis mellifera and Tetragonisca angustula against Staphylococcus aureus. J. Appl. Microbiol. v. 95(5), p.913-20, 2003.

Mirzoeva, O.K. et al. Antimicrobial action of propolis and some of its components: the effects on growth, membrane potential and motility of bacteria. Microbiol. Res, v.152, p.239-46,1997.

Monod M. et al. Survey of dermatophyte infections in the Lausanne area Switzerland. Dermatol. v.205(2), p.201-203, 2002.

Mors, W. B.; Natural Medicine, Ciência Hoje, v. 1, p.14, 1982.

Ogawa H. et al. Dermatophytes and host defense in cutaneous mycoses. Med. Mycol. 36(supplI): p.166-173, 1998.

Oliveira, A.C, et al. Antifungal activity of propolis extract against yeasts isolated from onychomycosis lesions. Mem. Inst. Oswaldo Cruz. v.101(5): 493-7, 2006.

Ota,C. et al. Antifungal activity of propolis on different species of Candida, Mycosis, v.44, p.375-378, 2001.

Ozcan, M. Inhibition of Aspergillus parasiticus NRRL 2999 by pollen and propolis extracts. J. Med Food, vol.7(1), p.114-6, 2004.

Park, Y.K \& Ikegaki, M. Preparation of water extracts of propolis and evaluation of the preparations. Biosc. Biotech. Biochem. v.62, p.2230-2, 1998.

Pascual, C. et al. Scavenging actino of propolis extract against oxigen radicals. J. Ethnopharmacol. v.41, p.9-13, 1994. 
Pereira, A.S. et al. Application of high resolution gas chromatography to crude extracts of propolis. J. High Res. Chrom., v.21(7), p.396-400, 1998.

Popova, M. et. al. Antibacterial activity of Turkish propolis and its qualitative and quantitative chemical composition. Phytom., v.12(3), p.221-8, 2005.

Rao, C.V. et al. Effect of caffeic acid esters on carcinogen- induced mutagenicity and human colon adenocarcinoma cell growth. Chem. Biol. Interact. v.84, p.277-90, 1992.

Rao, C.V. et al. Inhibitory effect of caffeic acid esters on azoximethane-induced biochemical changes and aberrant crypt foci formation in rat colon. Cancer Res. v.53, p.4182-8, 1993.

Rao, C.V. et al. Chemoprevention of colon carcinogenesis by phenylethyl-3methylcaffeate. Cancer Res. v.55, p.2310-15, 1995.

Said, R.A. Atividade antioxidante de diferentes concentrações dos extratos aquoso e etanólico da própolis, nas intoxicações agudas por acetaminofen, em camundongos. Viçosa, 84p. Dissertação (Mestrado)Faculdade de Medicina Veterinária- Universidade Federal de Viçosa, 2000.

Sawaya, A.C.H.F. et al. Comparative study of in vitro methods used to analyse the activity of propolis extracts with different compositions against species of Candida, Microbiol., v.35,p.203-207, 2002.

Scazzocchio, F. et al. Multifactorial aspects of antimicrobial activity of propolis. Microbiol Res. v.161(4), p.327-33, 2006.

Scheller, S. et al. Free radical scavenging by ethanol extract of propolis. International J. Rad. Biol. v.57, p.461-5, 1990.

Serra Bonvehi, J. \& Ventura Coll, F.The composition, active components and bacteriostatic activity of propolis on dietetics. J. Am. Chem. Soc., v.71, p.529-532, 1994. 
Siess, M.H. et al., Flavonoids of honey and propolis: characterization and effects on hepatic drug-metabolozing enzymes and benzopyrene-DNA binding in rats. J. Agric. Food Chem., Washington, v.44(8), p.2297-2301, 1996.

Silici, S. \& Koc, A.N. Comparative study of in vitro methods to analyse the antifungal activity of propolis agaist yeasts isolated from patients with superficial mycoses. Microbiol. v.43(3), p. 318-24, 2006.

Silva Cunha, I.B. et al. Antitrypanosomal activity of Brazilian propolis from Apis mellifera. Chem. Pharm. Bull (Tokyo), v.52(5), p.602-4, 2004.

Sohnle P.G. Dermatophytosis. In Fungal infections and immune responses. Plenum Press, New York, p.27-47, 1993.

Sonmez, S. et al. The effect of bee propolis on oral pathogens and human gingival fibroblasts. J. Ethnopharmacol. v.102(3), p.371-6, 2005.

Sousa, M.L, Isolamento dos contituintes de amostra de própolis e caracterização do perfil químico através de cromatografia líquida de alta eficiência, 113p. Dissertação de Mestrado- Faculdade de Ciências Farmacêuticas de Ribeirão Preto, Universidade de São Paulo, Ribeirão Preto, 1999.

Takaisi-Kikuni, N. B. \& Schilcher, H. Electron microscopic and microcalorimetric investigatioms of the possible mechanism of the antibacterial action of a defined propolis provenance. Planta Med. v.60, 222-227, 1994.

Ugur, A. \& Arslan, T. An in vitro study on antimicrobial activity of propolis from Mugla Province of Turkey. J. Med. Food, v.7(1), p.90-4, 2004.

Uzel, A. et. al. Chemical compositions and antimicrobial activities of four different Anatolian propolis samples. Microbiol. Res. v.160(2), p. 189-195, 2005.

Valdes, G. et al. Ensayo preliminar de la accion antifúngica de extractos de propoleo sobre Candida albicans. Ciencia Y Tecnica en la agriculturaApicultura, v.03, p.41-49, 1987. 
Valle, J. R. A Farmacologia no Brasil, Antecedentes e Perspectivas, Academia de Ciências do Estado de São Paulo: São Paulo, 1978.

Varanda, E. A. et al. Inhibitory effect of propolis and bee venon on the mutagenicity of some direct- and indirect-acting mutagens. Terat. Carc. Mutag. v.19, p.403-413, 1999.

Velikova, M. et al. Antibacterial ent-kaurene from Brazilian propolis of native stingless bees, Fitoterapia,v.72, p.693-696, 2000.

Vennat, B. et al., Qualitative and quantitative analysis of flavonoids and identification of phenolic acids from a propolis extract. J. Pharmacie Belgique, Bruxelle, v.50(5), p.438-444, 1995.

Vilela, J. D.; Natural life. Rev. Paul. Med., v.89, p.115. 1977.

Volpert, R. \& Elstner, E.F. Biochemical activities of propolis extracts. I Standardization and antioxidative properties of ethanolic and aqueous derivatives. Z. Naturforsch., v.48, p.851-7, 1993.

Wagner DK \& Sohnle PG, Cutaneous defenses against dermatophytes and yeasts, Clin. Microbiol. Rev. v.35, p.317-335, 1995.

Weitzman, I \& Summerbell, R. The dermatophytes. Clin. Microbiol., Rev. p.240-259, 1995.

Zais, N \& Rebell G. Chronic dermatophytosis caused by Trichophyton rubrum. J. Am. Acad. Dermatol. v. 35(3) p.17-20, 1996. 


\section{8-ANEXOS}

ANEXO I: Constituintes do Meio Sabouraud

$\mathrm{O} \mathrm{pH}$ do meio foi ajustado para 5,7. O meio foi autoclavado a $1 \mathrm{~atm}$ de pressão e $120^{\circ} \mathrm{C}$ por 20 min. Para preparo do meio sólido foi adicionado Ágar $1,5 \%(\mathrm{~m} / \mathrm{v})$. O meio Saboraud foi utilizado para o crescimento de Trichophyton rubrum.

\begin{tabular}{|l|l|}
\hline Meio Sabouraud & g elou $\mathrm{mL}$ \\
\hline Glicose & $20 \mathrm{~g}$ \\
Peptona & $10 \mathrm{~g}$ \\
Água destilada & $1000 \mathrm{~mL}$ \\
\hline
\end{tabular}

\section{Meios e soluções para Aspergillus nidulans}

ANEXO II: Preparo de Meio Completo.

$\mathrm{O} \mathrm{pH}$ foi ajustado para 6,8. O meio foi autoclavado a 1 atm de pressão e $120^{\circ} \mathrm{C}$ por 20 min. Para preparo do meio sólido foi adicionado agar 1,5\% (m/v). O meio completo foi utilizado para crescimento de Aspergillus nidulans.

\begin{tabular}{|l|l|}
\hline Meio Completo & g elou mL \\
\hline Solução de sais & $20 \mathrm{~mL}$ \\
Solução de casaminoácidos & $10 \mathrm{~mL}$ \\
Solução de ácidos nucléicos & $2,5 \mathrm{~mL}$ \\
Solução de vitaminas & $2,0 \mathrm{~mL}$ \\
Peptona & $2,0 \mathrm{~g}$ \\
Extrato de levedura & $1,0 \mathrm{~g}$ \\
Água destilada & $1.000 \mathrm{~mL}$ \\
\hline
\end{tabular}


ANEXO III: Solução de Sais.

As soluções apresentadas nas tabelas 3, 4, 5 e 6 foram mantidas sob clorofórmio $(2 \mathrm{~mL})$ a $4^{0} \mathrm{C}$.

\begin{tabular}{|l|l|}
\hline Solução de Sais & g elou $\mathrm{mL}$ \\
\hline Cloreto de potássio & $26 \mathrm{~g}$ \\
Sulfato de magnésio heptahidratado & $26 \mathrm{~g}$ \\
Fosfato de potássio monobásico & $76 \mathrm{~g}$ \\
Solução de elementos-traço & $50 \mathrm{~mL}$ \\
Água destilada estéril & $1000 \mathrm{~mL}$ \\
\hline
\end{tabular}

ANEXO IV: Solução de Elementos-Traço.

\begin{tabular}{|l|l|}
\hline Solução de Elementos-Traço & $\mathbf{m g}, \mathbf{g}$ e/ou $\mathbf{~ m L}$ \\
\hline Borato de sódio decahidratado & $40 \mathrm{mg}$ \\
Sulfato de cobre pentahidratado & $400 \mathrm{mg}$ \\
Sulfato de ferro heptahidratado & $532 \mathrm{mg}$ \\
Sulfato de manganês monohidratado & $292 \mathrm{mg}$ \\
Molibdato de sódio bihidratado & $800 \mathrm{mg}$ \\
Sulfato de zinco heptahidratado & $8 \mathrm{~g}$ \\
Água destilada estéril & $1000 \mathrm{~mL}$ \\
\hline
\end{tabular}


ANEXO V: Solução de Caseína Hidrolisada ou Casaminoácidos

\begin{tabular}{|l|l|}
\hline \multicolumn{1}{|c|}{$\begin{array}{c}\text { Solução de Caseína Hidrolisada ou } \\
\text { Casaminoácidos }\end{array}$} & g e/ou $\mathrm{mL}$ \\
\hline Caseína hidrolisada & \\
Água destilada estéril & $100 \mathrm{~g}$ \\
\hline
\end{tabular}

ANEXO VI: Solução de Vitaminas

Solução de ácidos nucléicos hidrolisados

Foi dissolvido $2 \mathrm{~g}$ de ácido nucléico de levedura em $15 \mathrm{~mL}$ de $\mathrm{HCl}$ e $2 \mathrm{~g}$ em 15mL de $\mathrm{NaOH}$. A solução foi aquecida por 20 minutos em banho-maria. Posteriormente, as soluções foram ajustadas em pH 6,0. A solução foi filtrada e o volume final foi completado para $40 \mathrm{~mL}$ com água destilada. A solução foi mantida em clorofórmio $(2 \mathrm{~mL})$, a $4^{0} \mathrm{C}$.

\begin{tabular}{|l|l|}
\hline \multicolumn{1}{|c|}{ Solução de Vitaminas } & $\mathbf{m g}$ elou $\mathbf{~ m L}$ \\
\hline Biotina & $1 \mathrm{mg}$ \\
Àcido p-aminobenzóico & $25 \mathrm{mg}$ \\
Ácido fólico & $10 \mathrm{mg}$ \\
Piridoxina & $50 \mathrm{mg}$ \\
Tiamina & $50 \mathrm{mg}$ \\
Ácido nicotínico & $100 \mathrm{mg}$ \\
Pantotenato de cálcio & $100 \mathrm{mg}$ \\
Cloreto de colina & $100 \mathrm{mg}$ \\
Riboflavina & $100 \mathrm{mg}$ \\
Mesoinositol & $200 \mathrm{mg}$ \\
Água destilada estéril & $100 \mathrm{~mL}$ \\
\hline
\end{tabular}


ANEXO VII: Solução de Glicose

As soluções apresentadas nas tabelas 7, 8 e 9 foram preparadas e autoclavadas e mantidas a $4^{0} \mathrm{C}$.

\begin{tabular}{|l|l|}
\hline \multicolumn{1}{|c|}{ Solução de Glicose } & g elou $\mathrm{mL}$ \\
\hline Glicose & $50 \mathrm{~g}$ \\
Água destilada estéril & $100 \mathrm{~mL}$ \\
\hline
\end{tabular}

ANEXO VIII: Solução de Nitrato de sódio

\begin{tabular}{|l|l|}
\hline \multicolumn{1}{|c|}{ Solução de Glicose } & g elou $\mathrm{mL}$ \\
\hline Nitrato de sódio & $59,5 \mathrm{~g}$ \\
Água destilada & $200 \mathrm{~mL}$ \\
\hline
\end{tabular}

ANEXO IX: Solução Salina + Tween

\begin{tabular}{|l|l|}
\hline \multicolumn{1}{|c|}{ Solução Salina + Tween } & g elou $\mathrm{mL}$ \\
\hline Cloreto de sódio & $9 \mathrm{~g}$ \\
Tween 80 & $0,1 \mathrm{~mL}$ \\
Água destilada & $1.000 \mathrm{~mL}$ \\
\hline
\end{tabular}




\section{Meio RPMI-1640}

Foi utilizado 10,4 g do meio RPMI-1640, sendo dissolvido em $900 \mathrm{~mL}$ de água destilada. A seguir foi adicionado ao MOPS uma concentração final de 0,165M, agitando-se até a completa dissolução do meio. $\mathrm{O} \mathrm{pH}$ foi ajustado para 7,0 utilizando hidróxido de sódio $1 \mathrm{M}$ e o volume completado para 1L com água destilada. O meio foi esterilizado por filtração e estocado a $-20^{\circ} \mathrm{C}$.

ANEXO X: Constituintes do meio RPMI- 1640.

\begin{tabular}{|c|c|c|c|}
\hline Constituinte & $\mathbf{g} / \mathbf{L}$ & Constituinte & $\mathbf{g} / \mathbf{L}$ \\
\hline L-arginina & 0,200 & Biotina & 0,0002 \\
L-asparagina & 0,050 & D-pantotênico & 0,00025 \\
Ácido L-aspártico & 0,020 & Cloreto de colina & 0,003 \\
L-cisteína.2HCL & 0,0652 & Ácido fólico & 0,001 \\
Ácido L-glutâmico & 0,020 & Mio-inositol & 0,035 \\
L-glutamina & 0,0300 & Niacinamida & 0,001 \\
Glicina & 0,010 & p-aminobenzóico & 0,001 \\
L-histidina & 0,015 & Piridoxina HCL & 0,001 \\
L-hidroxiprolina & 0,020 & Riboflavina & 0,0002 \\
L-isoleucina & 0,050 & Tiamina HCL & 0,001 \\
L-leucina & 0,050 & Vitamina B12 & 0,000005 \\
L-lisina HCL & 0,040 & Nitrato de cálcio & 0,100 \\
L-metionina & Cloreto de & 0,400 & - \\
& potássio & & \\
L-fenilalanina & 0,015 & Sulfato de magnésio & 0,04884 \\
L-prolina & 0,020 & Cloreto de sódio & 6,000 \\
L-serina & 0,030 & Fosfato de sódio & 0,800 \\
L-treonina & 0,020 & D-glicose & 2,000 \\
L-triptofano & 0,005 & Glutationa & 0,001 \\
L-tirosina 2Na & 0,020 & Vermelho de fenol & 0,0053 \\
L-valina & 0,020 & - & - \\
\hline
\end{tabular}

